\title{
Defective Anion Transport and Marked Spherocytosis with Membrane Instability Caused by Hereditary Total Deficiency of Red Cell Band 3 in Cattle Due to A Nonsense Mutation
}

\author{
Mutsumi Inaba, ${ }^{\star \ddagger}$ Ayumi Yawata, ${ }^{\S}$ Ichiro Koshino, ${ }^{*}$ Kota Sato, ${ }^{\ddagger}$ Miyuki Takeuchi, ${ }^{\ddagger}$ Yuichi Takakuwa," Sumie Manno,\| \\ Yoshihito Yawata,\$ Akio Kanzaki,§ Jun-ichi Sakai," Akira Ban," Ken-ichiro Ono, ${ }^{\star}$ and Yoshimitsu Maede \\ From the *Department of Veterinary Clinical Pathobiology, Faculty of Agriculture, The University of Tokyo, Tokyo, 113; ${ }^{*}$ Department of \\ Veterinary Internal Medicine, Faculty of Veterinary Medicine, Hokkaido University, Sapporo, 060; ${ }^{\S}$ Division of Hematology/Oncology, \\ Department of Medicine, Kawasaki Medical School, Kurashiki, 701-01; "Department of Biochemistry, Tokyo Women's Medical College, \\ Tokyo, 162; and "Veterinary Clinical Center, Yamagata Prefectural Federation of Agricultural Mutual Relief Association, Yamagata, \\ 990-21, Japan
}

\begin{abstract}
We studied bovine subjects that exhibited a moderate uncompensated anemia with hereditary spherocytosis inherited in an autosomal incompletely dominant mode and retarded growth. Based on the results of SDS-PAGE, immunoblotting, and electron microscopic analysis by the freeze fracture method, we show here that the proband red cells lacked the band 3 protein completely. Sequence analysis of the proband band $3 \mathrm{cDNA}$ and genomic DNA showed a $\mathrm{C} \rightarrow \mathrm{T}$ substitution resulting in a nonsense mutation (CGA $\rightarrow$ TGA; Arg $\rightarrow$ Stop) at the position corresponding to codon 646 in human red cell band $3 \mathrm{cDNA}$. The proband red cells were deficient in spectrin, ankyrin, actin, and protein 4.2, resulting in a distorted and disrupted membrane skeletal network with decreased density. Therefore, the proband red cell membranes were extremely unstable and showed the loss of surface area in several distinct ways such as invagination, vesiculation, and extrusion of microvesicles, leading to the formation of spherocytes. Total deficiency of band 3 also resulted in defective $\mathrm{Cl}^{-} / \mathrm{HCO}_{3}{ }^{-}$exchange, causing mild acidosis with decreases in the $\mathrm{HCO}_{3}{ }^{-}$ concentration and total $\mathrm{CO}_{2}$ in the proband blood. Our results demonstrate that band 3 indeed contributes to red cell membrane stability, $\mathrm{CO}_{2}$ transport, and acid-base homeostasis, but is not always essential to the survival of this mammal. (J. Clin. Invest. 1996. 97:1804-1817.) Key words: band $3 \cdot$ anion transport $\bullet$ acid-base homeostasis $\bullet$ red cell membrane $\bullet$ hereditary spherocytosis
\end{abstract}

This study was presented in part at the Second International Congress of Pathophysiology, 19-24 November 1994, Kyoto, Japan, and was published in abstract form (1994. Inaba, M., M. Takeuchi, K. Sota, K. Ono, and Y. Maede. Pathophysiology. 1[Suppl.]:235).

Address correspondence to Mutsumi Inaba, D.V.M., Ph.D., at his current address: Department of Veterinary Clinical Pathobiology, Faculty of Agriculture, The University of Tokyo, Yayoi 1-1-1, Bunkyo-ku, Tokyo, 113, Japan. Phone: 81-3-3812-2111, ext. 5471; FAX: 81-3-5684-5194; E-mail: ainazo@hongo.ecc.u-tokyo.ac.jp

Received for publication 20 June 1995 and accepted in revised form 26 January 1996.

J. Clin. Invest.

(C) The American Society for Clinical Investigation, Inc.

0021-9738/96/04/1804/14 \$2.00

Volume 97, Number 8, April 1996, 1804-1817

\section{Introduction}

Band 3 (anion exchanger 1, AE1), the most abundant transmembrane glycoprotein in mammalian red blood cells, functions as an anion transporter mediating $\mathrm{Cl}^{-} / \mathrm{HCO}_{3}{ }^{-}$exchange across the plasma membrane (1-4). This rapid process of exchange increases by fivefold the capacity of the blood to carry $\mathrm{CO}_{2}$ from respiring tissues to the lungs $(4,5)$ and maintains blood acid-base homeostasis $(2,6)$ in concert with the function of renal band 3, which is involved in $\mathrm{HCO}_{3}{ }^{-}$reabsorption and $\mathrm{H}^{+}$secretion $(4,7,8)$. Band 3 also participates in maintaining mechanical properties of red cells by attaching the spectrinactin network to the plasma membrane through association with ankyrin (9). As a consequence of its physiological importance, it has been presumed that band 3 is essential to the survival of mammals.

In recent years, several hereditary disorders (10-16) and partial deficiencies $(17,18)$ of human red cell band 3 have been reported and have provided some important findings for understanding its structure-function relationship, roles in membrane skeleton organization, and the pathobiology of inherited red cell membrane disorders $(4,19)$. Southeast Asian ovalocytosis $(\mathrm{SAO})^{1}$ is the best-documented disease in which band 3 gene mutations $(10,12,13)$ cause decreased anion transport activity (14) and membrane rigidity (10). Several other disorders of band 3 involve mutations that cause protein 4.2 deficiency and atypical hereditary spherocytosis $(15,16)$. Furthermore, Jarolim et al. $(17,18)$ recently demonstrated that heterozygotic patients possessing other mutations, namely band $3^{\text {PRAGUE }}$ and band $3^{\text {PRAGUE II }}$, show a $\sim 40 \%$ deficiency of their red cell band 3 and exhibit a decrease in 4,4'-diisothiocyano-2,2'-stilbene disulfonate (DIDS)-inhibitable $\mathrm{SO}_{4}{ }^{2-}$ flux to $\sim 50 \%$ of that in normal cells. As regards the spherocyte formation in hereditary spherocytosis associated with band 3 deficiency, it has been proposed that the loss of surface area is caused by the release of bilayer lipids, possibly containing band 3 , in the form of membrane skeleton-free lipid vesicles $(20,21)$. However, there is no definitive evidence on the morphological and physiological consequences of a lack of band 3 function, since neither aberrant band 3-ankyrin linkage nor a complete lack of band 3-mediated anion transport has been found in nature. No homozygotic patient, in fact, has been re-

1. Abbreviations used in this paper: DIDS, 4,4'-diisothiocyano-2,2'stilbene disulfonate; EM, electron microscopy; Hct, hematocrit; IMP, intramembrane particle; $\mathrm{pH}_{\mathrm{i}}$, intracellular $\mathrm{pH}$; QFDE, quick-freeze deep etching; SAO, Southeast Asian ovalocytosis. 
ported in SAO (22) and other inherited disorders of red cell band 3 . In this respect, previous investigators suggested that defects of anion transport in the kidney and red cells of SAO patients may make homozygosity for a variant band 3 lethal $(4,14)$.

Recently, we found that several Japanese black cattle exhibiting moderate anemia and retarded growth had congenital hereditary spherocytosis. We analyzed the red cell membrane proteins of the affected cattle by SDS-PAGE, and found, surprisingly, that their red cells totally lacked band 3 . The purpose of the present study is to examine the molecular basis of this complete deficiency, and to demonstrate physiological and morphological consequences of this novel aberrant defect of the red cell anion exchanger.

Case report. Severe hemolytic anemia was found in nine newborn Japanese black calves (P1-P9, three females and six males) in Yamagata Prefecture, Japan, from 1991 through 1995. The calves were weak and small (18-25 kg birth weight; normally $25-30 \mathrm{~kg}$ ) and unable to stand or suckle by themselves at birth. They showed labored breathing, palpitation, pale and/or icteric visible mucosal membranes with increased indirect bilirubin concentrations $(2.0-6.0 \mathrm{mg} / \mathrm{dl})$, and splenomegaly in all cases. Hematological examination revealed severe intravascular hemolysis with significant decreases in hematocrit (Hct) values of 10-18\%. All calves showed typical spherocytosis in which most of the red cells were microcytic spherocytes with remarkably increased osmotic fragility exhibiting $\sim 80 \%$ hemolysis even with $0.85 \% \mathrm{NaCl}$ solution. Direct and indirect Coombs' tests showed negative results, negating the possibility of autoimmune disorders.

The proband (P2, male) and three affected animals, P1 and P4 (both male) and P9 (female), survived to adulthood after 2-6 d of conservative medication, although their growth was retarded. One male calf (P5) survived to weaning but then died at 4 mo of age. Another male (P6) and a female (P7) died within several days after birth. The rest (a female [P3] and a male [P8]) were killed on days 7 and 10, respectively, because they exhibited little clinical improvement. None of these dead or killed subjects received prompt and adequate supportive care at birth. One of them had a congenital heart anomaly. Autopsies of the dead and killed calves revealed marked jaundice and splenomegaly. Histochemically, accumulations of bilirubin in the liver and hemosiderin in renal tubules and congestion and dilatation of red pulp areas of the spleen were evident. P2, P4, and P9 have been housed over 4, 2, and $1.5 \mathrm{yr}$, respectively, without significant clinical manifestations except for moderate anemia (Hct $=23-33 \%$; see Table I for P2) and retarded growth. P2 was castrated before weaning. Unfortunately, P1 was slaughtered at 13 mo of age after the first blood examination. In the present study, therefore, $\mathrm{P} 2$ and $\mathrm{P} 4$ were the main subjects for analyses.

We have studied the large family of cattle including the affected animals. The dams and siblings showed no clinical symptoms, including anemia and growth retardation. However, blood examination revealed the presence of spherocytes in peripheral blood from the dams and some siblings, although the proportions of the spheric cells were as low as $2-5 \%$. Slightly increased osmotic fragilities were observed for their red cells, particularly when examined at $24 \mathrm{~h}$ after blood collection. Hence, hereditary spherocytosis was diagnosed in the recent population of the pedigree. The inheritance appeared to be in an autosomal incompletely dominant mode, although the blood of sires was not available.

\section{Methods}

Clinical studies. Venous blood was drawn from the proband and normal healthy adult cattle (Japanese black and Holstein). Routine hematological parameters were determined on an automated cell counter (System 9000; Serono-Baker Diagnostics, Allentown, PA). Gatings for counting red cells and platelets were 21-300 and 1.8-18.3, respectively. The diluents used in automatic counting had no significant effect on red cell counts and red cell parameters determined by manual methods. Small red cell fragments and vesicles extruded from the cells, when present, were detected in the gate for platelets. Microscopic examination of red cells was carried out on blood films stained with Giemsa. The reticulocytes were counted after supravital staining with new methylene blue. The osmotic fragility test was done by the method of Beutler (23).

Preparation of membranes from red cells, bone marrow cells, and kidneys. Bovine red cell membranes were prepared as reported previously (24). In some experiments, membranes were obtained from red cells digested with trypsin (25).

Bone marrow cells were obtained from the sternum of each sick animal ( $\mathrm{P} 2$ and $\mathrm{P} 4)$ and a control cow under sedation with xylazine and stored at $-80^{\circ} \mathrm{C}$. The cells were homogenized in $5 \mathrm{mM}$ Tris $/ \mathrm{Cl}$, $\mathrm{pH}$ 7.8, $1 \mathrm{mM}$ EDTA, $1 \mathrm{mM}$ PMSF, $0.5 \mu \mathrm{g} / \mathrm{ml}$ leupeptin, and $0.5 \mu \mathrm{g} /$ $\mathrm{ml}$ pepstatin $\mathrm{A}$ on ice followed by centrifugation at $500 \mathrm{~g}$ for $5 \mathrm{~min}$ at $4^{\circ} \mathrm{C}$. The supernatants were centrifuged at $18,000 \mathrm{~g}$ for $30 \mathrm{~min}$ at $4^{\circ} \mathrm{C}$. The crude membrane fraction obtained as a pellet was resuspended in the same buffer.

Kidneys were obtained from a normal healthy adult cow and one of the sick animals (P3). Slices of the kidneys consisting of cortex and medulla were stored at $-80^{\circ} \mathrm{C}$ until use. Kidney tissues were homogenized in homogenization buffer $(250 \mathrm{mM}$ sucrose, $1 \mathrm{mM}$ Tris/EDTA, $\mathrm{pH} 7.4,1 \mathrm{mM}$ PMSF, $0.5 \mu \mathrm{g} / \mathrm{ml}$ leupeptin, and $0.5 \mu \mathrm{g} / \mathrm{ml}$ pepstatin A) on ice. Homogenates were centrifuged at 2,000 $\mathrm{g}$ for $15 \mathrm{~min}$ at $4^{\circ} \mathrm{C}$. The supernatants were centrifuged at $18,000 \mathrm{~g}$ for $30 \mathrm{~min}$ at $4^{\circ} \mathrm{C}$. The crude membrane fraction obtained as a pellet was resuspended in the same buffer.

Protein concentrations of the membrane preparations were determined by the method of Bradford (26) with a protein assay kit (BioRad Laboratories, Richmond, CA) using BSA as the standard.

SDS-PAGE and immunoblotting. SDS-PAGE using Laemmli's system (27) and immunoblotting were performed as described previously (28). Polyclonal antibodies raised against several different domains of bovine band 3 , an anti-38 kD cytoplasmic domain (anti$38 \mathrm{~K}$ ), anti-17 kD transmembrane domain (anti-17K), and anti-41 kD transmembrane domain including the carboxyl terminus (anti-41K) $(25,29)$, were generous gifts from Drs. Ryuichi Moriyama and Shio Makino (School of Agricultural Sciences, Nagoya University, Nagoya, Japan). Antiserum against the $8.5-\mathrm{kD}$ carboxyl-terminal peptide of human band 3 (30) was a kind gift from Dr. Naotaka Hamasaki (Faculty of Medicine, Kyushu University, Fukuoka, Japan). Antibodies to human protein 4.2 (31), canine spectrin and ankyrin (24), and BSA (Seikagaku Co., Tokyo, Japan) were also used.

Reverse transcription, PCR, and sequencing analysis of band 3 $c D N A$ and genomic DNA. In the present study, nucleotides and amino acid residues were numbered according to those of the human red cell band $3(32,33)$, since only partial amino acid sequences have been reported for the bovine band 3 protein $(29,34)$.

Total bone marrow cell RNA was prepared from a normal cow, and the proband was prepared by the guanidine thiocyanate method and reverse transcribed using oligo(dT)12-18 primers and SuperScript reverse transcriptase (GIBCO BRL, Gaithersburg, MD). The cDNAs obtained were amplified by PCR using a GeneAmp PCR reagents kit (Perkin-Elmer Corp., Norwalk, CT) (35 cycles, 1 min at $94^{\circ} \mathrm{C}, 1 \mathrm{~min}$ at $55^{\circ} \mathrm{C}, 1 \mathrm{~min}$ at $72^{\circ} \mathrm{C}$ ) or LA PCR reagents kit (Takara, Otsu, Japan) ( 35 cycles, $40 \mathrm{~s}$ at $94^{\circ} \mathrm{C}, 40 \mathrm{~s}$ at $58^{\circ} \mathrm{C}, 2 \mathrm{~min}$ at $\left.68^{\circ} \mathrm{C}\right)$ in a TempTronic thermal cycler (Thermolyne, Dubuque, IA) with combinations of PCR primers, p15 (5'-GCTGGGGGCTCAGATCACCG-3'; bases -48 to -29 ), p5 (5'-CGTGATATCCGGCGC- 
CGCTAC-3'; bases 1,150 to 1,170$)$, p14 (5'-GCAAACATCATCCAGATGGGA-3'; bases 1,997 to 1,977), and p12 (5'-CCACAAGCACAGCGACCAGGA-3'; bases 2,311 to 2,291). PCRamplified cDNA fragments were cloned into the pCRII vector using a TA cloning kit (Invitrogen, San Diego, CA), and inserts were sequenced on both strands using a dye primer cycle sequencing kit (PRISM; Perkin-Elmer Corp.) on an ABI 373A DNA sequencer.

Segments of the band 3 gene were also amplified by PCR (30 cycles, $40 \mathrm{~s}$ at $94^{\circ} \mathrm{C}, 40 \mathrm{~s}$ at $60^{\circ} \mathrm{C}$, and $1 \mathrm{~min}$ at $72^{\circ} \mathrm{C}$ ) using primers p17 (5'-AAACTCAGTGTACCTGAAGGC-3'; bases 2,041 to 2,061) and p14 or p20 (5'-GTGGTGATCTGGGACTCAAGGA-3'; bases 2,207 to 2,186 ), cloned and sequenced as described above. Primers p17 and p20 were prepared based on the sequence of bovine band 3 cDNA fragments as determined above.

Determination of cell chloride concentration. The chloride concentration and water content of bovine red cells were determined essentially as described by Knauf et al. $(35,36)$ and Law et al. (37). Red cells were incubated at $37^{\circ} \mathrm{C}$ for $3 \mathrm{~h}$ in PBSG $(10 \mathrm{mM} \mathrm{Na}$ phosphate, $\mathrm{pH} 7.4,150 \mathrm{mM} \mathrm{NaCl}$, and $5 \mathrm{mM}$ glucose) containing $1.0 \mu \mathrm{Ci} / \mathrm{ml}$ $\mathrm{Na}^{36} \mathrm{Cl}(12.9 \mathrm{mCi} / \mathrm{g}$ of $\mathrm{Cl}$; ICN Biomedicals, Irvine, CA $)$ and $10 \mu \mathrm{Ci} /$ $\mathrm{ml}\left[\mathrm{methoxy}-{ }^{3} \mathrm{H}\right]$ inulin $(300 \mathrm{mCi} / \mathrm{g}$, Du Pont-New England Nuclear, Boston, MA). The cells were centrifuged at $16,000 \mathrm{~g}$ for $5 \mathrm{~s}$ at $4^{\circ} \mathrm{C}$, after which as much of the supernatant as possible was removed. Radioactivities of ${ }^{36} \mathrm{Cl}^{-}$and ${ }^{3} \mathrm{H}$ in the red cell pellet and the supernatant were counted after deproteinization in $0.25 \%$ (vol/vol) Triton X-100 and $2.5 \%$ (wt/vol) TCA using ReadyCap (Beckman, Fullerton, CA) as the scintillant. The $\mathrm{Cl}^{-}$content of the red cells was calculated from the radioactivity of ${ }^{36} \mathrm{Cl}^{-}$per cell, which was corrected for extracellular space by using the radioactivity of $\left[\right.$ methoxy $\left.-{ }^{3} \mathrm{H}\right]$ inulin. To determine cell water content, the cell pellet obtained as above was weighed before and after drying at $80^{\circ} \mathrm{C}$ for $2 \mathrm{~d}$. Cell water was calculated by subtracting the dry weight and the water in the extracellular space, estimated from parallel experiments with $\left[\right.$ methoxy- $\left.{ }^{3} \mathrm{H}\right]$ inulin, from the wet weight of the cell pellet. Cell numbers, mean corpuscular volume of the cells, and hemoglobin concentration were determined using an automated cell counter.

Measurement of chloride fluxes. To determine the period required for transmembranous equilibrium of $\mathrm{Cl}^{-}$in the proband red cells, we first measured ${ }^{36} \mathrm{Cl}^{-}$content at appropriate incubation times as $\mathrm{Cl}^{-}$influx by the procedure described above. That is, the red cells were incubated in the presence of ${ }^{36} \mathrm{Cl}^{-}$and $\left[\right.$methoxy- $\left.{ }^{3} \mathrm{H}\right]$ inulin for $0-1 \mathrm{~h}$ at $37^{\circ} \mathrm{C}$ or at $20^{\circ} \mathrm{C}$. Whereas control bovine red cells showed a near equilibrium distribution of ${ }^{36} \mathrm{Cl}^{-}$across the membrane even at time 0 , presumably because of the rapid flux during handling, the proband red cells had a quite slow uptake of ${ }^{36} \mathrm{Cl}^{-}$, and the incorporation at time 0 was calculated to be negative in some experiments. We therefore used an alternative method, rapid centrifugation (38), to measure the $\mathrm{Cl}^{-}$influx into the proband red cells precisely.

The proband red cells were incubated at an Hct value of $20 \%$ in $200 \mu \mathrm{l}$ of PBSG containing $1.0 \mu \mathrm{Ci} / \mathrm{ml} \mathrm{Na}{ }^{36} \mathrm{Cl}$ at $37^{\circ} \mathrm{C}$ for various periods $(0-4 \mathrm{~h})$. After incubation, the cells were immediately placed on ice and diluted with $1.0 \mathrm{ml}$ of ice-chilled PBSG and centrifuged at $16,000 \mathrm{~g}$ for $5 \mathrm{~s}$ at $4^{\circ} \mathrm{C}$. The cells were washed three times with $1.0 \mathrm{ml}$ of PBSG at $4^{\circ} \mathrm{C}$ by repeated centrifugation. After the final wash at $16,000 \mathrm{~g}$ for $10 \mathrm{~s}$, the packed cells were lysed and deproteinized by the addition of $200 \mu \mathrm{l}$ each of $0.5 \%$ (vol/vol) Triton X-100 and 5\% (wt/ vol) TCA, and the radioactivity of the supernatant was counted. The value at time 0 was obtained by following the same procedure immediately after mixing the cells with $\mathrm{Na}^{36} \mathrm{Cl}$ on ice. This procedure gave results similar to those obtained by the method described above except that the uptake at time 0 was negligible rather than negative. During $4 \mathrm{~h}$ of incubation, $\sim 3.5 \%$ of red cells were lost by hemolysis and no significant volume change was observed.

Chloride efflux measurement was performed essentially as reported by Knauf et al. $(35,36)$. The red cells from normal control cattle and the proband were incubated at an Hct value of $30 \%$ in PBSG containing $2.0 \mu \mathrm{Ci} / \mathrm{ml} \mathrm{Na}^{36} \mathrm{Cl}$ at $37^{\circ} \mathrm{C}$ for $3 \mathrm{~h}$ and then at $20^{\circ} \mathrm{C}$ for 20 min, and sedimented at 2,000 $\mathrm{g}$ for $15 \mathrm{~min}$ at $20^{\circ} \mathrm{C}$, and as much of the supernatant as possible was discarded. About $100 \mu \mathrm{l}$ of the packed red cells was flushed into $10 \mathrm{ml}$ of PBSG or PBSG in which $\mathrm{NaHCO}_{3}$ was partly substituted for $\mathrm{NaCl}$. Incubation was carried out at $20^{\circ} \mathrm{C}$ in the presence or absence of 10-50 $\mu$ M DIDS (Dojin Chemical Laboratories, Kumamoto, Japan) with gentle agitation. At the appropriate time $(t), 500 \mu \mathrm{l}$ of the cell suspension was centrifuged at $16,000 \mathrm{~g}$ for $5 \mathrm{~s}$ at $4^{\circ} \mathrm{C}$, and the supernatant was counted for radioactivity of ${ }^{36} \mathrm{Cl}^{-}$ $\left(P_{\mathrm{t}}\right)$ released from the cells. Total radioactivity of ${ }^{36} \mathrm{Cl}^{-}$involved in the same volume of cell suspension $\left(P_{\text {inf }}\right)$ was obtained after deproteinization with $250 \mu \mathrm{l}$ of $10 \%$ TCA. The logarithm of $P_{\text {inf }} /\left(P_{\text {inf }}-P_{\mathrm{t}}\right)$ was calculated and plotted against time (37).

Blood gases and acid-base balance. For quantitation of blood gases and blood $\mathrm{pH}$, blood was drawn from the artery and vein of the tail using heparin lithium as an anticoagulant. Blood gases and $\mathrm{pH}$ were determined within $10 \mathrm{~min}$ after sampling by using an IL-1306 auto blood gas analyzer system (Instrumentation Laboratory, Milan, Italy). The values were corrected for body temperature $(38.5 \pm 0.15$ $(\mathrm{SD})^{\circ} \mathrm{C}, n=9$ ) for control cattle and $38.6^{\circ} \mathrm{C}$ (the mean of two measurements) for the proband. Intracellular $\mathrm{pH}(\mathrm{pHi})$ of bovine red cells was measured as described (39). In brief, red cells were washed three times with unbuffered $1 \%(\mathrm{wt} / \mathrm{vol}) \mathrm{NaCl}$ solution and suspended to yield an Hct value of $20 \%$. After lysis of red cells by the addition of $0.1 \%(\mathrm{vol} / \mathrm{vol})$ Triton $\mathrm{X}-100, \mathrm{pH}$ values of the hemolysate were measured using a $\mathrm{pH}$ meter (Beckman) and defined as the $\mathrm{pHi}$ values. Urine samples were collected, and the $\mathrm{pH}$ was measured within $30 \mathrm{~min}$ after sampling.

\section{Electron microscopic analyses}

Morphological studies of red blood cells. Scanning electron micrography (EM) was performed on red cells fixed with $0.1 \mathrm{M}$ Na phosphate, $\mathrm{pH} 7.4$, containing $1.0 \%$ glutaraldehyde using a scanning electron microscope (model S-570; Hitachi Ltd., Tokyo, Japan).

Freeze fracture method. The intact red cells were also examined by the freeze fracture method by fixation in $1.0 \%$ glutaraldehyde, followed by impregnation with $10-40 \%$ glycerol as described previously (40). The cell suspensions were rapidly immersed in Freon 22 cobled in liquid nitrogen. The freeze fracture replicas were prepared in a Balzers BAF 301 apparatus (Balzers, Liechtenstein) and then examined with an electron microscope (JEM 2000 EX-II; JEOL Ltd., Tokyo, Japan) at $200 \mathrm{kV}$.

Immunogold labeling. The intact red cells were fixed in $0.1 \mathrm{M} \mathrm{Na}$ phosphate, $\mathrm{pH} 7.4$, containing $2 \%$ paraformaldehyde and $0.1 \%$ glutaraldehyde at $4^{\circ} \mathrm{C}$ overnight, followed by impregnation with Lowicryl K4M (Chemische Werke Lowi, Waldkraiburg, Germany). Ultrathin sections were placed on nickel grids. After blocking with $1 \%$ egg albumin, rabbit anti-bovine serum albumin antibody (Seikagaku Corp., Tokyo, Japan) was applied at $4^{\circ} \mathrm{C}$ overnight in a 1:100 dilution with $5 \mathrm{mM}$ Tris/Cl, $\mathrm{pH}$ 8.2. After washing with PBS, gold conjugate antirabbit IgG (10 nm; Biocell, Cardiff, UK) was applied at room temperature for $45 \mathrm{~min}$ in a 1:20 dilution. The specimens were then fixed with $2 \%$ glutaraldehyde solution, treated with uranyl acetate for 6 min and then with lead citrate for $2 \mathrm{~min}$, and subjected to transmission EM at $80 \mathrm{kV}(41)$.

Quick-freeze deep etching (QFDE) method. QFDE was applied for transmission EM as described previously (42). Red cell ghosts were frozen rapidly to $-196^{\circ} \mathrm{C}$ with a quick-freeze apparatus (MF-2; Eiko Co., Tokyo, Japan). The specimens were cut with the Balzers BAF 301 apparatus and were subjected to etching at $-100^{\circ} \mathrm{C}$ at $5 \times$ $10^{-5} \mathrm{~Pa}$ for $5 \mathrm{~min}$. Rotary replication was carried out with platinum at an angle of $20^{\circ}(2 \mathrm{~nm})$ and with carbon at an angle of $90^{\circ}(20 \mathrm{~nm})$. Film thickness was controlled by the frequency shift on a Balzers quartz crystal monitor (QSG 201D). The replica was placed onto copper grids (300 mesh) and subjected to transmission EM at $200 \mathrm{kV}$.

Negative staining method. Red cell ghosts were placed onto copper grids coated with $0.1 \%$ poly-L-lysine. Excessive red cell ghosts were washed out with $5 \mathrm{mM}$ phosphate buffer. The specimens were negatively stained by uranyl acetate, essentially by the method of Liu et al. (43), and examined by transmission EM at $80 \mathrm{kV}$. 


\section{Results}

Clinical and morphological studies. The proband (P2) showed severe Coombs negative hemolytic anemia ( Hct $=13 \%$ ) at birth as described in the Introduction under the heading "Case report." However, it has exhibited no clinical manifestations since 1 mo after its birth, except that it had attacks of fever $\left(\sim 40^{\circ} \mathrm{C}\right)$, continuing for $2-3 \mathrm{~d}$ several times in the first year, uncompensated anemia, and retarded growth. The body weight of the proband at $2 \mathrm{yr}$ of age was $250 \mathrm{~kg}$, only $\sim 50 \%$ that of normal Japanese black cattle of corresponding age. Periodic examination of blood from the animal from 1 to $2 \mathrm{yr}$ of age revealed that the anemia was moderate and chronic (Table I). Intravenous hemolysis was not evident and the serum indirect bilirubin concentration was within the normal range, although hemolysis was sometimes evident if blood was drawn with strong suction. The red cell morphology of the proband resembled that of spherocytosis and anisocytosis with an elevated mean corpuscular volume and a slightly diminished mean corpuscular hemoglobin concentration. The cells constantly showed considerably increased osmotic fragility with $50 \%$ hemolysis at $\sim 0.75 \% \mathrm{NaCl}$ while the normal range was $0.48-$ $0.55 \% \mathrm{NaCl}$ (Table I). Several other affected animals (P1, P4, and P9) that survived to adulthood (see "Case report" in the Introduction) exhibited basically the same clinical histories. It is not surprising that no significant increase in reticulocytes was observed since cattle are known to release few reticulocytes into the peripheral blood even when hematopoiesis is accelerated by serious anemia (44). Instead, orthochromatic erythroblasts sometimes appeared on blood films. Moreover, bone marrow aspirates of the animals examined (P2 and P4) revealed increased erythropoiesis with an $\mathrm{M} / \mathrm{E}$ ratio of 0.53

Table I. Hematological Parameters of the Proband

\begin{tabular}{lcc}
\hline & $\begin{array}{c}\text { Control } \\
(n=20)^{*}\end{array}$ & $\begin{array}{c}\text { Proband } \\
(n=17)^{*}\end{array}$ \\
\hline $\mathrm{RBC}\left(\times 10^{6 / \mu \mathrm{l})}\right.$ & $7.8 \pm 0.7$ & $4.9 \pm 0.6$ \\
$\mathrm{Hb}(\mathrm{g} / \mathrm{dl})$ & $12.5 \pm 0.5$ & $8.3 \pm 0.9$ \\
$\mathrm{Hct}(\%)$ & $35.8 \pm 2.8$ & $25.1 \pm 2.6$ \\
$\mathrm{MCV}(\mathrm{fl})$ & $45.9 \pm 2.6$ & $51.3 \pm 2.3$ \\
$\mathrm{MHC}(\mathrm{pg})$ & $16.1 \pm 1.3$ & $17.1 \pm 1.0$ \\
$\mathrm{MCHC}(\%)$ & $35.1 \pm 1.6$ & $33.4 \pm 2.0$ \\
Reticulocyte $(\%)$ & $<0.1$ & $<0.1$ \\
WBC $\left(\times 10^{3} / \mu \mathrm{l}\right)$ & $8.2 \pm 4.3$ & $14.0 \pm 4.0$ \\
$\quad$ Neutrophils $(\%)$ & $16.3 \pm 6.2$ & $10.7 \pm 3.8$ \\
Lymphocytes $(\%)$ & $63.8 \pm 3.9$ & $78.0 \pm 7.5$ \\
Monocytes $(\%)$ & $4.5 \pm 1.2$ & $5.36 \pm 1.4$ \\
$\quad$ Eosinophils $(\%)$ & $15.5 \pm 3.1$ & $6.0 \pm 2.9$ \\
Platelets $\left(\times 10^{3} / \mu \mathrm{l}\right)$ & $278 \pm 117$ & $307 \pm 93$ \\
Indirect bilirubin $(\mathrm{mg} / \mathrm{dl})$ & $0.6 \pm 0.5$ & 0.7 \\
Osmotic fragility, $\mathrm{NaCl}$ concentration & & \\
$\quad$ at $50 \%$ hemolysis $(\%)$ & $0.48-0.55$ & 0.75 \\
& & \\
\hline
\end{tabular}

*Control hematological parameters were obtained from 20 adult healthy cattle (Japanese black and Holstein) and expressed as means \pm SD. Data of the proband were means \pm SD obtained from 17 repeated examinations from November 1992 through November 1993 except for bilirubin (mean of two examinations) and osmotic fragility (mean of four examinations).
$0.56(\mathrm{M} / \mathrm{E}$ ratio $=0.70-0.75$ in normal cows $)$ and contained many reticulocytes. Urobilinogen was normal and hemoglobin was not detectable in urinalysis.

Scanning electron microscopic analysis of bovine blood demonstrated that the red cells of the proband greatly varied in size, being principally spherocytic and stomatocytic with numerous small globules on their cell surface (Fig. $1 B$ ), whereas normal cells exhibited a uniform size and biconcave disk shape (Fig. $1 A$ ). These figures show the red cells fixed $6 \mathrm{~h}$ after blood was drawn. The numerous globules observed on the proband red cells were removed by washing the cells with PBS at room temperature without noticeable hemolysis. The resultant stomatocytic spherocytes had irregular contours with a small number of protrusions as shown in Fig. $1 C$. When the freshly drawn blood was fixed immediately, normal and proband red cells essentially showed morphological features like those in Fig. 1, $A$ and $C$, respectively.

Abnormalities of red cell membrane proteins. The red cell membrane proteins of the proband showed a quite abnormal profile on SDS gels stained with Coomassie brilliant blue (Fig. $2 A)$. The most aberrant defect was the lack of the band 3 protein $\left(M_{\mathrm{r}} \sim 105,000\right)$, an anion exchanger, which comprises $\sim 25 \%$ of total membrane proteins in normal bovine red cells. We analyzed the proband red cell membranes by immunoblotting using several antibodies to the band 3 protein such as anti-38K, anti-17K, and anti-41K $(25,29)$. As shown in Fig. $2 B$, normal band 3 was appropriately recognized with these antibodies, whereas no polypeptides were immunospecifically detected in the red cell membranes from the proband. In addition, no bands were observed in the proband membranes on the immunoblots using an antibody against the $8.5-\mathrm{kD}$ carboxyl-terminal peptide (not shown), which is essential for anion transport activity of human red cell band 3 (30). Increasing the amount of proteins or loading whole red cell lysates onto the gels had no effect on these observations (not shown). In the blot using anti-38K, bands with $M_{\mathrm{r}}>200 \mathrm{kD}$ were observed sometimes both in the proband and control. These bands appeared to be bovine spectrin nonspecifically reacting to the antibodies since the band intensity was greatly reduced after spectrin extraction from the membranes in low-ionic-strength buffer (not shown). Complete lack of band 3 in immunoblotting was demonstrated in all cases (P1-P9, not shown). These results demonstrated that the red cells of the affected animals completely lacked the band 3 protein.

The electrophoretic profiles of the red cell membranes from equivalent volumes of control and proband-packed cells (Fig. $2 A$ ) also revealed an apparent deficiency of protein 4.2 and considerable decreases in other major components such as spectrin, actin, and glyceraldehyde 3-phosphate dehydrogenase (band 6) in the proband. We obtained $3.75 \mathrm{mg}$ of membrane proteins from $1.0 \mathrm{ml}$ of the packed control cells, whereas the proband red cells yielded only $1.80 \mathrm{mg}$ of proteins. These values corresponded to the average content of membrane protein per cell of $12.8 \mathrm{pg}$ for the normal bovine red cell and $7.6 \mathrm{pg}$ for the proband cell. Thus, the content of membrane proteins in the proband red cell appeared to be as low as $60 \%$ that of the normal cell. Immunoblotting analysis demonstrated very low content or a nearly complete lack of protein 4.2 in red cell membranes of the proband (Fig. 2 C). Moreover, a reduction of ankyrin content in the proband cells by at least $50 \%$ compared with that in normal cells was demonstrated (Fig. $2 C$ ). It should be noted that differences between the contents of pro- 

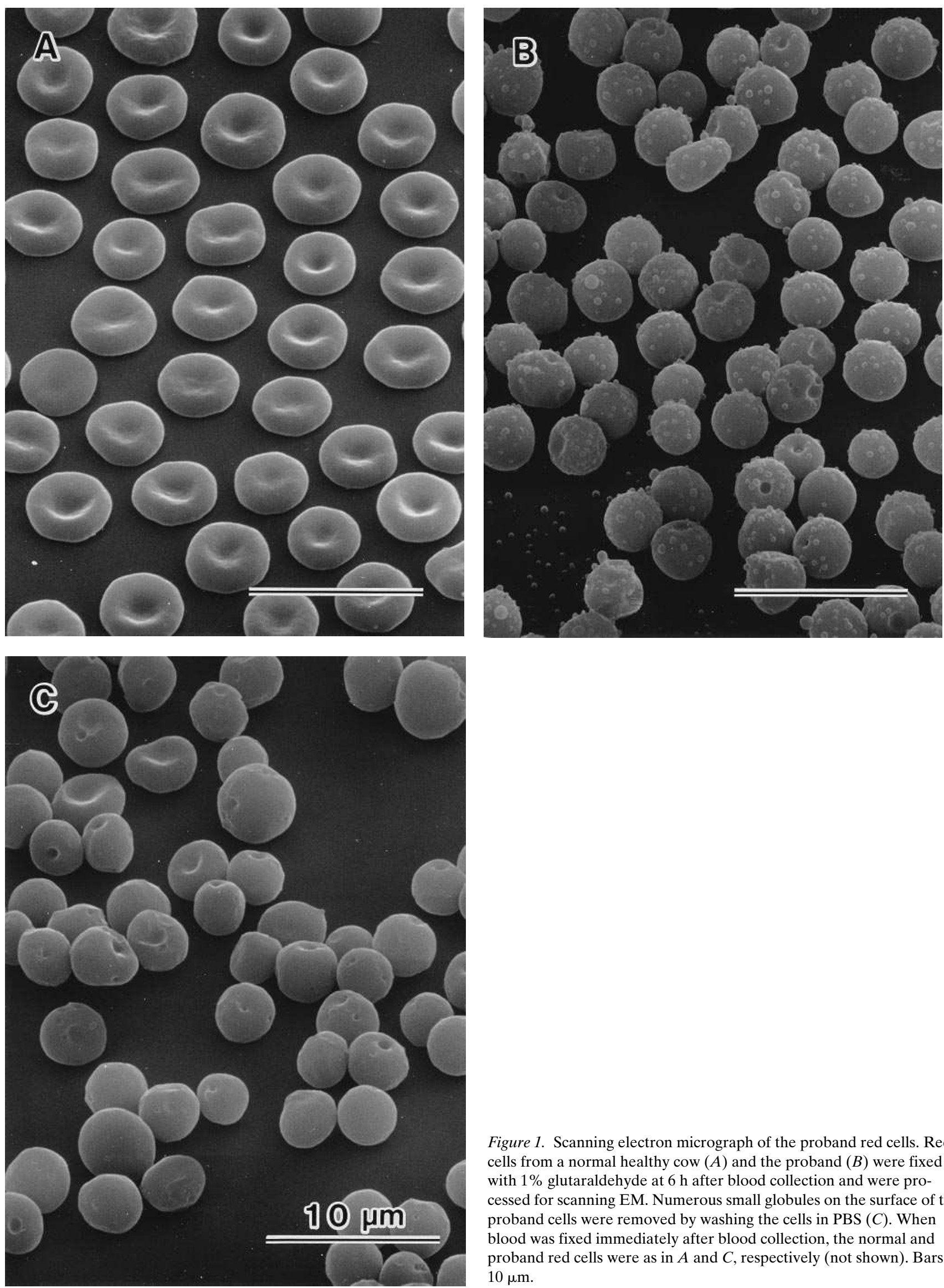

Figure 1. Scanning electron micrograph of the proband red cells. Red cells from a normal healthy cow $(A)$ and the proband $(B)$ were fixed with $1 \%$ glutaraldehyde at $6 \mathrm{~h}$ after blood collection and were processed for scanning EM. Numerous small globules on the surface of the proband cells were removed by washing the cells in PBS $(C)$. When blood was fixed immediately after blood collection, the normal and proband red cells were as in $A$ and $C$, respectively (not shown). Bars, $10 \mu \mathrm{m}$ 


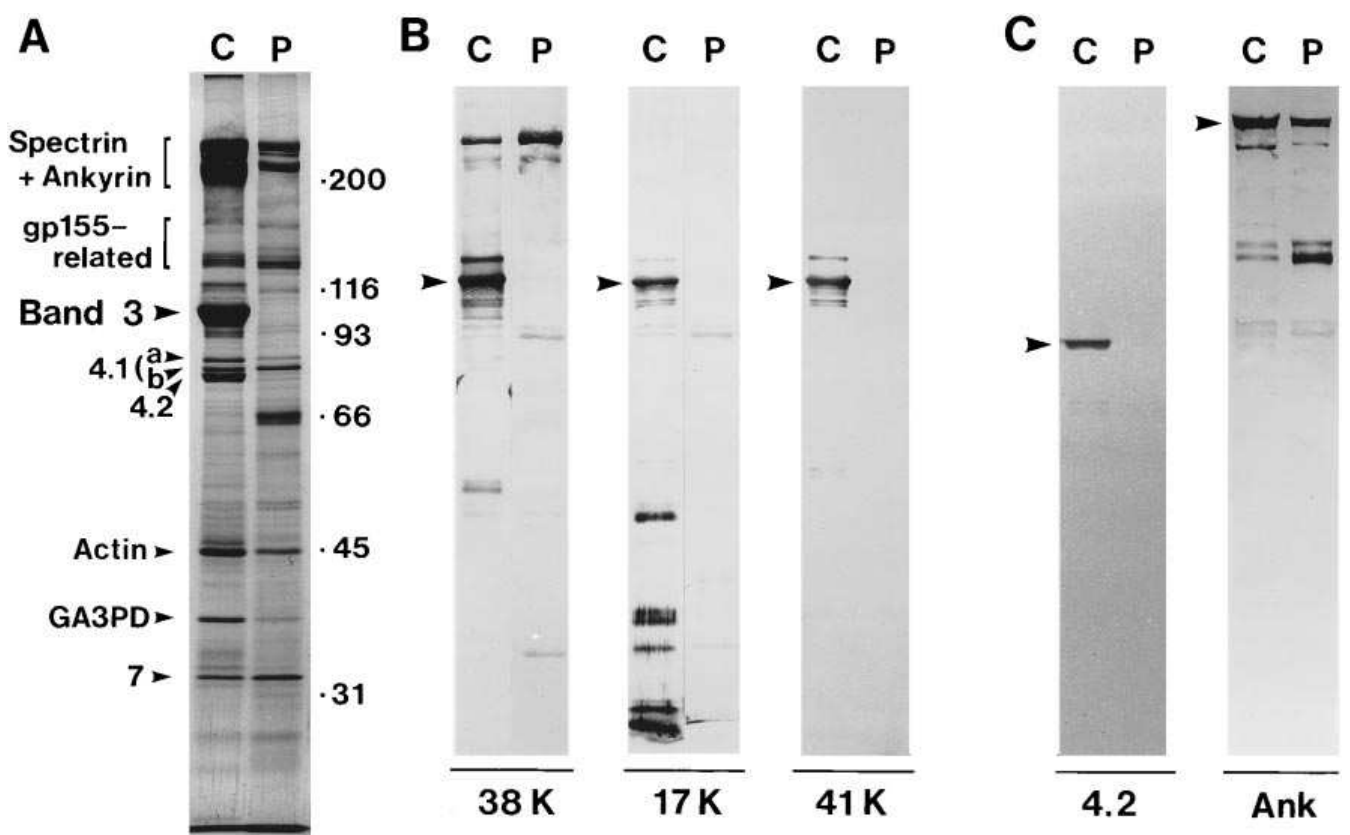

Figure 2. Deficiency of band 3 and other membrane proteins in the proband. $(A)$ SDS-PAGE profiles of red cell membrane proteins. Ghost membranes were prepared from the equivalent volumes of packed red cells from the control cow $(C)$ and the proband $(P)$, the volumes of the membrane suspensions were adjusted to be the same, and they were analyzed on $8 \%$ SDS gel followed by staining with Coomassie brilliant blue. Major proteins and migrating positions of the standard proteins $\left(M_{\mathrm{r}}\right.$ in $\left.\times 10^{-3}\right)$ are indicated. $(B)$ Immunoblot analysis of the band 3 protein. Membrane proteins from control red cells $(C)$ and the proband red cells $(P)$ were separated on $8 \%$ SDS gels and analyzed

for band 3 by immunoblotting. Antibodies used were anti-38K $(38 \mathrm{~K})$, anti-17K $(17 \mathrm{~K})$, and anti-41K $(41 \mathrm{~K})$. It should be noted that the amounts of the proteins loaded were $3 \mu \mathrm{g}$ for control cells and $20 \mu \mathrm{g}$ for proband cells. The migrating position of band 3 is indicated. Bands with $M_{\mathrm{r}}>200$ $\mathrm{kD}$ in the blot using anti-38K were observed sometimes both in the proband and control and appeared to be bovine spectrin nonspecifically reacting to the antibodies (see text). $(C)$ Protein $4.2(4.2)$ and ankyrin $(A n k)$ in control $(C)$ and proband $(P)$ red cell membranes were detected by immunoblotting. Proteins applied to the gel were $3 \mu \mathrm{g}(C)$ and $20 \mu \mathrm{g}(P)$. Protein 4.2 and ankyrin are indicated by arrowheads.

tein 4.1 and some other minor transmembrane proteins such as gp155-related polypeptides (24) and Na,K-ATPase in the control and the proband membranes were not obvious as judged by SDS-PAGE and immunoblotting (not shown). Densitometric scanning of the separated proteins showed that, in the proband red cells, spectrin ( + ankyrin) and actin levels were 26 and 44\%, respectively, whereas protein 4.1 and gp155related polypeptides were 87 and $78 \%$, respectively, of those in normal cells. A $66-\mathrm{kD}$ protein, comprising $\sim 10 \%$ of the total proteins, was found only in the sick animal (Fig. $2 A$ ) and was proved by immunoblotting to be bovine albumin (not shown).
Markedly reduced numbers of intramembrane particles (IMPs) on electron microscopy (EM) by the freeze fracture method. Intact red cells were subjected to EM using the freeze fracture method, and representative results are shown in Fig. 3. The numbers, sizes, and distribution patterns of the IMPs in normal controls appeared to be perfectly intact (Fig. $3 A$ ). In the proband (Fig. $3 B$ ), the number of IMPs was decreased by $\sim 70 \%\left(1,856 \pm 226 / \mu \mathrm{m}^{2}, n=10\right)$ compared with that of normal cattle $\left(5,373 \pm 292 / \mu \mathrm{m}^{2}, n=10\right)$ in which band 3 as a major constituent of the IMPs (usually $80 \%$ of total IMPs in human red cell membranes [45]) is present normally. The IMPs in the

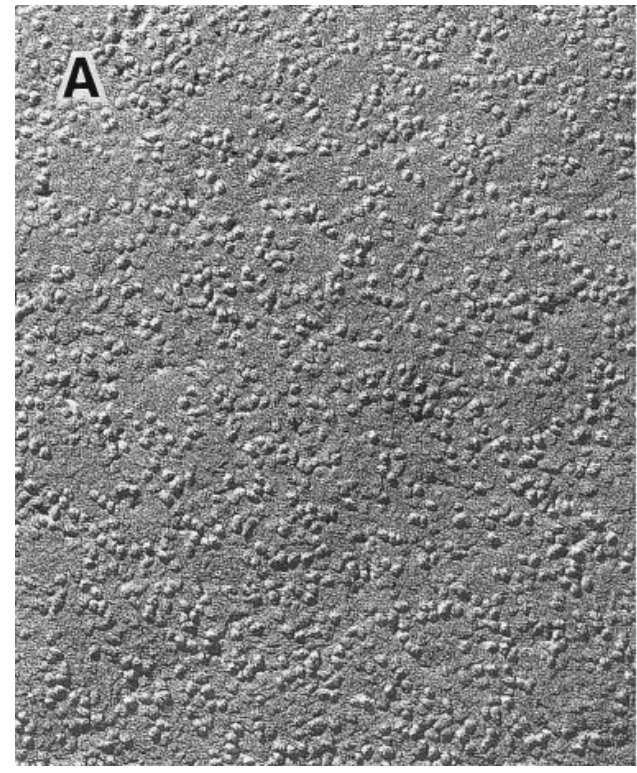

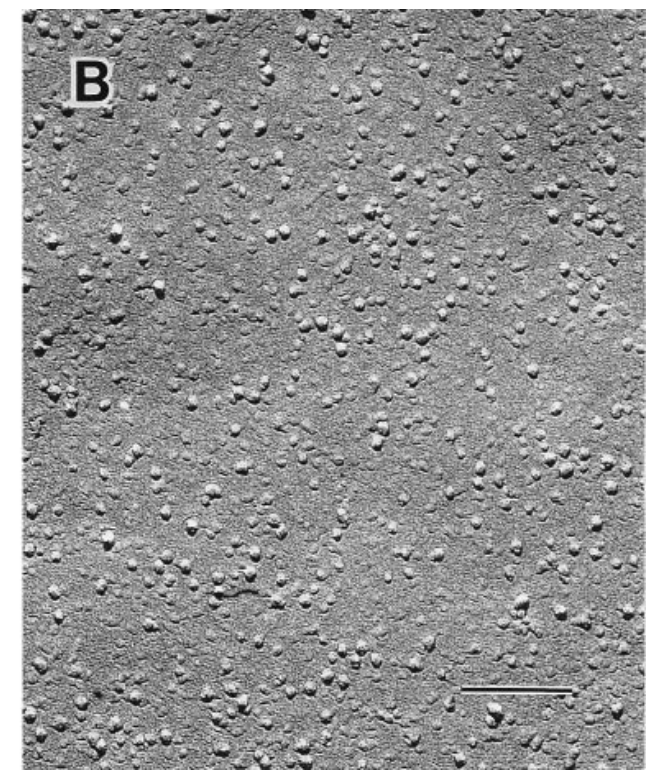

Figure 3. Markedly reduced number of IMPs accompanying bovine red cell band 3 deficiency on electron micrographs by the freeze fracture method. The intact red cells were fixed with $1.0 \%$ glutaraldehyde and examined by the freeze fracture method. As compared with normal bovine red cells $(A)$, the number of IMPs was markedly reduced in the proband red cells (B) by $\sim 70 \%$. Bar, $0.1 \mu \mathrm{m}$; magnification is 200,000 . 

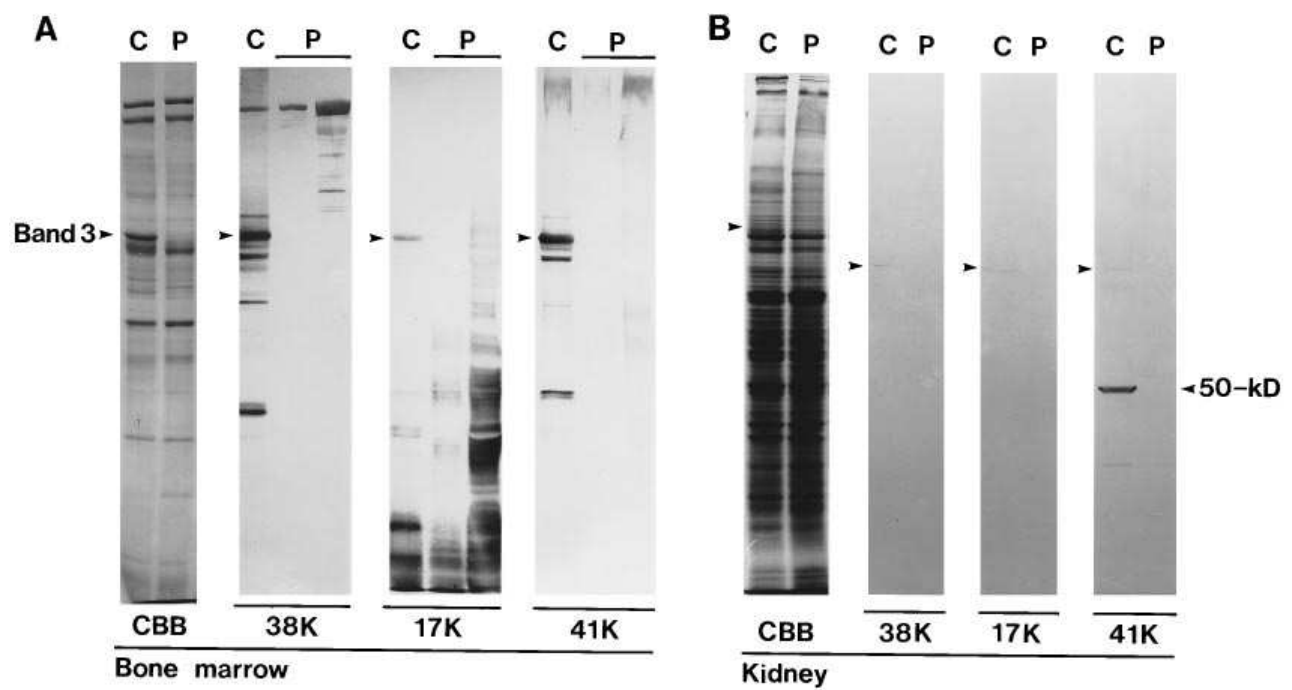

Figure 4. Detection of the band 3 protein in bovine bone marrow cells and kidney. Membrane proteins of bone marrow cells $(A)$ and kidney $(B)$ from the control $(C)$ and an affected animal $(P)$ were analyzed by SDS-PAGE followed by staining the gels with $\mathrm{Coo}-$ massie brilliant blue $(C B B)$ or by immunoblotting using anti-38K $(38 K)$, anti-17K $(17 K)$, and anti$41 \mathrm{~K}(41 K)$. In immunoblotting, lane $C$ contained $10 \mu \mathrm{g}(A)$ and $100 \mu \mathrm{g}(B)$, lane $P$ contained $10 \mu \mathrm{g}$ (left) or $100 \mu \mathrm{g}$ (right) in $A$ and 100 $\mu \mathrm{g}$ in $B$. Red cell band $3(105-\mathrm{kD})$ and the $50-\mathrm{kD}$ band in the kidney are indicated. Bands with $M_{\mathrm{r}}>$ $200 \mathrm{kD}$ found in $38 K$ in $A$ are due to nonspecific staining of spectrin as in Fig. 2. Broad smear bands

with $M_{\mathrm{r}}$ of $<60 \mathrm{kD}$ reacting with anti-17K in the proband membranes also appeared to be nonspecific, since these bands were not observed in the blot using anti-38K and anti-41K by which polypeptide regions flanking the $17-\mathrm{kD}$ domain would be recognized.

proband were distributed rather randomly, in contrast to the orderly distribution of the IMPs in the normal cow. Therefore, the IMPs present in the protoplasmic face in the sick animal appeared to be some intramembrane components rather than band 3, i.e., various glycoproteins, such as gp155 (24), glyco- phorins, etc., although we have no direct evidence because the immunogold method could not be applied for the freeze fracture studies by EM. There was no significant difference in the number of IMPs on the exoplasmic face in EM between the normal and the affected animals, indicating that some in-
A

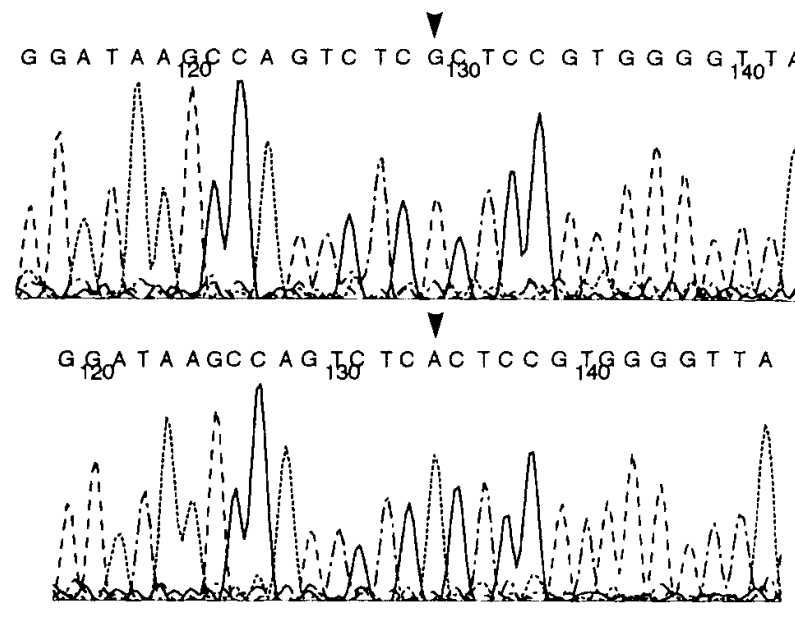

B

$\begin{array}{lllll} & 641 & 646 & 651 \\ \text { Human } & \text { Ser Asn Ser Ser Ala Arg Gly Trp Val lle His } \\ & \text { TCC AAC TCC TCA GCC CGG GGC TGG GTC ATC CAC }\end{array}$

Cattle

Normal Ser Asn Pro Thr Glu Arg Asp Trp Leu lle His
TCT AAC CCC ACG GAG CGA GAC TGG CTT ATC CAC

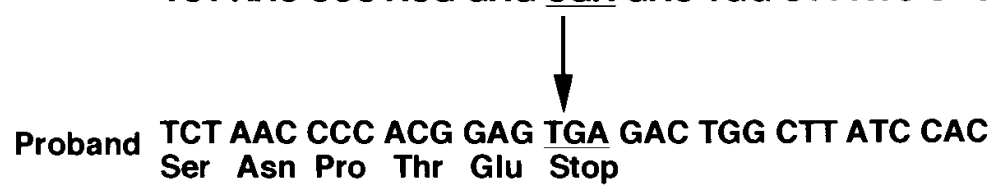

Figure 5. Analysis of the proband band 3 cDNA. (A) Nucleotide sequences of the control (upper panel) and proband (lower panel) band $3 \mathrm{cDNAs}$ corresponding to nt 1,924 to 1,947 (from right to left) in human band 3 cDNA. Here, the sequence of the antisense strand is shown and the point mutation site is indicated by an arrowhead. (B) Substitution $\mathrm{C} \rightarrow \mathrm{T}$ at nucleotide 1,936 changing codon 646 from CGA to TGA (Arg $\rightarrow$ Stop). The deduced amino acid sequence of this region was consistent with that determined by direct amino acid sequencing for one of the proteolytic peptides $\left(\mathrm{Leu}^{632}\right.$ $\cdots-\mathrm{Leu}^{649}$ ) from bovine band 3 (Makino, S., and Moriyama, R., personal communication). Top alignment shows nucleotide and amino acid sequences for the corresponding region of human band $3(32,33)$. 

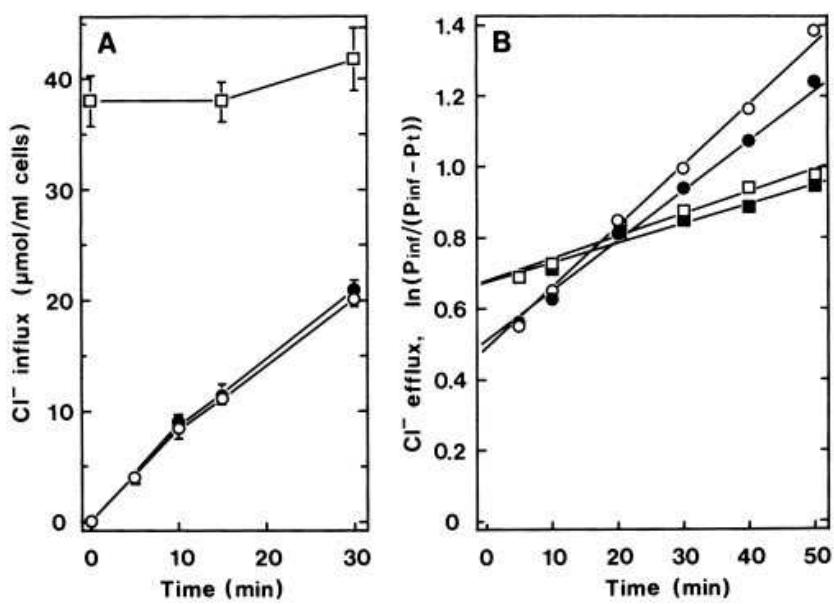

Figure 6. Chloride fluxes in red cells from normal and proband cattle. (A) Influx of $\mathrm{Cl}^{-}$into the proband red cells was estimated at $20^{\circ} \mathrm{C}$ in the presence $(\bullet)$ or absence $(O)$ of $50 \mu \mathrm{M}$ DIDS by the rapid centrifugation method described in Methods. $\mathrm{Cl}^{-}$influx into control bovine red cells at $20^{\circ} \mathrm{C}$ determined by an alternative method using $\mathrm{Na}^{36} \mathrm{Cl}$ and $\left[{ }^{3} \mathrm{H}\right]$ inulin is also shown $(\square)$. Data are expressed as means $\pm \mathrm{SD}(n=4)$. (B) Efflux of $\mathrm{Cl}^{-}$under transmembrane equilibrium was measured at $20^{\circ} \mathrm{C}$ for the proband cells $(\bigcirc$ and $\bullet)$ and the control red cells ( $\square$ and $\boldsymbol{\square}$ ) in the absence (proband) or presence (control) of $10 \mu \mathrm{M}$ DIDS. Extracellular medium contained $0(\bigcirc$ and $\square)$ or $25 \mathrm{mM}(\bullet$ and $) \mathrm{HCO}_{3}^{-}$. The slopes gave the rate constants shown in Table II. Values are the means of three independent experiments.

tramembrane particles (most likely gp155, glycophorins, and others) other than band 3 were unaffected even in the proband (not shown).

Defects of bone marrow cells and kidney band 3 in the proband. We analyzed the crude membrane fraction from proband bone marrow aspirate enriched in reticulocytes and erythroid precursors to test whether the precursor cells contained band 3 protein or relevant polypeptides. As demonstrated in Fig. $4 A$, no immunospecific bands recognized by anti-38K or anti-41K antibodies were detected in the bone marrow cell membranes of the proband, whereas the control showed immunoblot profiles similar to those of the red cell membranes. Although we did not study further the many bands with an $M_{\mathrm{r}}$ of $<60 \mathrm{kD}$ that reacted only with anti-17K in the proband membranes, we could conclude, at least, that erythroid precursor cells of the proband lacked the normal band 3 molecule as demonstrated in the mature cells.

The crude membrane fraction from normal bovine kidney (medulla and cortex) contained a predominant $50-\mathrm{kD}$ protein that showed substantial immunoreactivity to a polyclonal antibody (anti-41K) against the 41-kD membrane domain, and a $\sim 105-\mathrm{kD}$ protein corresponding to red cell band 3 with very faint intensity (Fig. $4 \mathrm{~B}$ ). However, antibodies to different regions of band 3 (the $38-\mathrm{kD}$ cytoplasmic domain and $17-\mathrm{kD}$ membrane domain) did not detect the $50-\mathrm{kD}$ protein. As documented in Fig. 4 , no bands were seen when the renal membranes from the affected animal were subjected to immunoblotting. We therefore concluded that the affected animals lacked the kidney protein, which is antigenically related to band 3, as in the erythroid cells.

Sequencing analysis of band $3 c D N A$ and genomic DNA. Because the above studies suggested that some molecular de- fect within the band 3 gene caused total deficiency of band 3 in the proband, we isolated total bone marrow cell RNA and reverse transcribed it into cDNA. Both normal and proband cDNA gave bands of identical sizes after amplification with primer pairs p15-p14 (2.1 kb), p5-p14 (0.85 kb), and p5-p12 $(1.2 \mathrm{~kb})$, spanning $\sim 2.4 \mathrm{~kb}$ encoding the entire cytoplasmic domain and the 2/3 transmembrane domain (data not shown). Sequencing analysis of a portion of these PCR-amplified fragments showed a $\mathrm{C} \rightarrow \mathrm{T}$ substitution in the proband $\mathrm{CDNA}$, resulting in a nonsense mutation (CGA $\rightarrow$ TGA; Arg $\rightarrow$ Stop) at the position corresponding to amino acid 646 (Fig. 5) in human band 3 cDNA $(32,33)$.

We then amplified and cloned the region of genomic DNA from affected animals P2 and P4 flanking the $\mathrm{Arg}^{646} \rightarrow$ Stop mutation, and we confirmed the presence of this nonsense mutation in their genomic DNA. We also cloned the same segment of genomic DNA from the dams of these animals and obtained two types of clones. Approximately 50\% of the clones had the normal bovine band 3 sequence as determined above; the remainder contained the nonsense mutation, $\mathrm{Arg}^{646} \rightarrow$ Stop, indicating that the dams were heterozygous for this mutation.

Anion fluxes in the band 3-deficient red cells. The $\mathrm{Cl}^{-}$influx into the normal cells was too fast to measure with ${ }^{36} \mathrm{Cl}^{-}$, and the content of ${ }^{36} \mathrm{Cl}^{-}$in the cells appeared to reach the maximum value within a short period of centrifugation and handling (Fig. $6 \mathrm{~A}$ ). In contrast to the normal cells, the $\mathrm{Cl}^{-}$influx into the proband red cells at $20^{\circ} \mathrm{C}$ was very slow, so we could measure the flux rate easily. It required $\sim 2 \mathrm{~h}$ to reach transmembranous equilibrium even at $37^{\circ} \mathrm{C}$ (not shown). Fig. 6 also shows that the influx was not affected by $\sim 50 \mu \mathrm{M}$ DIDS, a potent inhibitor of anion transport via band $3(2,46)$. Incubation of the proband cells before the flux assay with $\sim 50 \mu \mathrm{M}$ DIDS at $25^{\circ} \mathrm{C}$ for $30 \mathrm{~min}$, which is sufficient to block the band 3-mediated transport irreversibly (46), had no effect on these observations (not shown).

Based on these results, to estimate $\mathrm{Cl}^{-}$exchange under equilibrium conditions, the proband red cells were loaded with ${ }^{36} \mathrm{Cl}^{-}$for $3 \mathrm{~h}$ at $37^{\circ} \mathrm{C}$, and the efflux of ${ }^{36} \mathrm{Cl}^{-}$from the cells was measured at $20^{\circ} \mathrm{C}$ as a function of time. The logarithm of $P_{\text {inf }} f$ $\left(P_{\text {inf }}-P_{\mathrm{t}}\right)$ plotted against time exhibited a straight line (Fig. 6 $B)$, demonstrating, in the proband red cells, $\mathrm{Cl}^{-}$exchanges with a single rate constant of 0.0164 (Table II) given by the slope of the line (35). Whereas $\mathrm{Cl}^{-}$exchange in normal bovine red cells was inhibited by $10 \mu \mathrm{M}$ DIDS to a rate constant of 0.0064 (Fig. $6 \mathrm{~B}$ ), no significant effect of DIDS was observed for the $\mathrm{Cl}^{-}$exchange in the proband cells (Fig. 6 and Table II). Here, the flux rate of $\mathrm{Cl}^{-}$in the band 3-deficient cells was very slow compared with that in the control cells, in which $\mathrm{Cl}^{-}$ transport via band 3 was inhibited by DIDS. However, partial substitution of $\mathrm{HCO}_{3}^{-}$for $\mathrm{Cl}^{-}$in the medium caused a decrease in ${ }^{36} \mathrm{Cl}^{-}$efflux from the proband cells (Fig. $6 \mathrm{~B}$ and Table II), indicating that $\mathrm{Cl}^{-}$and $\mathrm{HCO}_{3}{ }^{-}$shared the same transport system even in the band 3-deficient red cells. These results suggested that the proband red cells might possess some unidentified anion exchange system very different from band 3 in terms of the anion transport activity and sensitivity to DIDS.

The $\mathrm{Cl}^{-}$content and the $\mathrm{Cl}^{-}$concentration in the proband red cells determined under equilibrium conditions were reduced to $\sim 75$ and $80 \%$ of those in normal red cells, respectively, as shown in Table II. Therefore, the $\mathrm{Cl}^{-}$exchange flux, 


\begin{tabular}{|c|c|c|c|c|c|c|c|}
\hline \multirow{3}{*}{$\begin{array}{l}\text { Anion } \\
\text { DIDS }(10 \mu \mathrm{M})^{\S}\end{array}$} & \multicolumn{2}{|c|}{ Control red cells } & \multicolumn{4}{|c|}{ Proband red cells } & \multirow{3}{*}{$\begin{array}{c}\begin{array}{c}\text { Human } \\
\text { red cells* }\end{array} \\
\mathrm{Cl}^{-} \\
-\end{array}$} \\
\hline & \multirow{2}{*}{$\frac{\mathrm{Cl}^{-}}{+}$} & \multirow{2}{*}{$\begin{array}{c}\mathrm{Cl}^{-/} \\
\mathrm{HCO}_{3}^{-\ddagger} \\
+\end{array}$} & \multicolumn{2}{|c|}{$\mathrm{Cl}^{-}$} & \multicolumn{2}{|c|}{$\mathrm{Cl}^{-} / \mathrm{HCO}_{3}^{-\frac{+}{+}}$} & \\
\hline & & & - & + & - & + & \\
\hline $\mathrm{Cl}^{-}$exchange rate constant $\left(\min ^{-1}\right)$ & 0.0064 & 0.0059 & 0.0164 & 0.0162 & 0.0145 & 0.0147 & 180.8 \\
\hline $\mathrm{Cl}^{-}$content $(\mathrm{fmol} /$ cell $)$ & \multicolumn{2}{|c|}{$2.59 \pm 0.25$} & \multicolumn{4}{|c|}{$1.96 \pm 0.21$} & 6.99 \\
\hline Cell water $(\mathrm{fl} /$ cell $)$ & \multicolumn{2}{|c|}{$22.9 \pm 2.9$} & \multicolumn{4}{|c|}{$22.4 \pm 1.5$} & 60.9 \\
\hline Intracellular $\mathrm{Cl}^{-}$concentration $(\mathrm{mM})$ & \multicolumn{2}{|c|}{$106.4 \pm 10.4$} & \multicolumn{4}{|c|}{$87.2 \pm 9.6$} & 115 \\
\hline $\mathrm{Cl}^{-}$exchange flux (fmol/cell per min) & 0.0166 & 0.0153 & 0.0321 & 0.0317 & 0.0284 & 0.0288 & 1,264 \\
\hline
\end{tabular}

The contents of $\mathrm{Cl}^{-}$and intracellular water were determined for red cells from control and the proband as described in Methods. Data are the means \pm SD $(n=4)$ for the control cattle and the means \pm SD of three independent measurements for the proband cells. Chloride exchange rates were obtained by multiplication of the $\mathrm{Cl}^{-}$content per cell and the rate constants given by the slopes of the straight lines shown in Fig. 6 . * Reference data on human red cells at $25^{\circ} \mathrm{C}(62) .{ }^{\ddagger} \mathrm{Cl}^{-} / \mathrm{HCO}_{3}{ }^{-}$means $25 \mathrm{mM} \mathrm{NaHCO}$ was substituted for $\mathrm{NaCl}$. ${ }^{\S}$ When present, DIDS was included in the reaction at $10 \mu \mathrm{M}$.

calculated as the product of the rate constant and the $\mathrm{Cl}^{-}$content (35), in proband cells was only twice that of control cells treated with DIDS. We also found that the transport of $\mathrm{SO}_{4}{ }^{2-}$ in the red cells from the proband was much slower and much less sensitive to DIDS than in red cells from normal cattle (not shown). These results indicated that the proband red cells completely lacked rapid anion exchange, the function of band 3 protein, and that the defective $\mathrm{Cl}^{-} / \mathrm{HCO}_{3}{ }^{-}$exchange in these cells was uncompensated for and limited to a rather low level.

Blood gases and acid-base balance in the proband. In the proband, both arterial and venous blood showed a decrease in the $\mathrm{HCO}_{3}{ }^{-}$concentration to $\sim 75 \%$ of that in control cattle (Table III), presumably because the proband cells transported little $\mathrm{HCO}_{3}{ }^{-}$out as demonstrated above. Thus, the total $\mathrm{CO}_{2}$ in the proband blood was again $\sim 75 \%$ of that in normal blood. Moreover, the proband blood showed a significantly decreased $\mathrm{pH}$ value compared with the normal blood $(\sim 0.15$ $\mathrm{pH} \mathrm{U}$; Table III), demonstrating that the lowered $\mathrm{HCO}_{3}{ }^{-}$level due to the defective anion exchange in the red cells caused mild but chronic acidosis. Interestingly, the pHi of the proband red cells was higher than the blood $\mathrm{pH}$, whereas the $\mathrm{pHi}$ of normal red cells was $\sim 0.2 \mathrm{pH}$ U less than the blood $\mathrm{pH}$. It should also be noted that the anion gap value, obtained as $\mathrm{Na}^{+}-\left(\mathrm{Cl}^{-}+\mathrm{HCO}_{3}^{-}\right)$, in the sick animal was very similar to that in normal cattle, because of the slightly reduced $\mathrm{Na}^{+}$concentration. Urine $\mathrm{pH}$ of the proband was slightly lower than

Table III. Blood Gases and Acid-Base Homeostasis in Bovine Band 3 Deficiency

\begin{tabular}{|c|c|c|c|c|}
\hline & \multicolumn{2}{|c|}{ Arterial blood } & \multicolumn{2}{|c|}{ Venous blood } \\
\hline & Control & Proband & Control & Proband \\
\hline $\mathrm{pH}$ & $7.43 \pm 0.04$ & 7.30 & $7.34 \pm 0.04$ & 7.17 \\
\hline $\mathrm{pH}_{\mathrm{i}}$ & & & $7.27 \pm 0.04^{*}$ & 7.41 \\
\hline $\mathrm{PCO}_{2}(\mathrm{mmHg})$ & $36.1 \pm 2.2$ & 36.9 & $47.6 \pm 2.8$ & 53.2 \\
\hline $\mathrm{PO}_{2}(\mathrm{mmHg})$ & $110.6 \pm 13.9$ & 103.5 & $30.1 \pm 3.0$ & 32.5 \\
\hline $\mathrm{HCO}_{3}^{-}(\mathrm{mEq} /$ liter $)$ & $24.3 \pm 2.0$ & 18.5 & $25.9 \pm 2.5$ & 19.6 \\
\hline Total $\mathrm{CO}_{2}$ (mEq/liter) & $25.4 \pm 2.0$ & 19.6 & $27.3 \pm 2.5$ & 21.3 \\
\hline Base excess (mEq/liter) & $0.8 \pm 2.3$ & -6.5 & $0.56 \pm 2.9$ & -8.2 \\
\hline $\mathrm{O}_{2}$ saturation & $98.3 \pm 0.7$ & 97.4 & $52.6 \pm 8.7$ & 55.9 \\
\hline $\mathrm{Cl}^{-}(\mathrm{mEq} /$ liter $)$ & $104.4 \pm 5.6$ & 101.5 & $101.2 \pm 4.0$ & 104.0 \\
\hline $\mathrm{Na}^{+}$(mEq/liter) & $146.2 \pm 4.5$ & 138.5 & $145.4 \pm 1.1$ & 139.0 \\
\hline $\mathrm{K}^{+}(\mathrm{mEq} /$ liter $)$ & $3.8 \pm 0.2$ & 4.7 & $4.3 \pm 0.4$ & 4.4 \\
\hline Anion gap (mEq/liter) & $17.3 \pm 2.0$ & 18.6 & $16.4 \pm 0.8$ & 16.1 \\
\hline \multirow[t]{2}{*}{ Urine $\mathrm{pH}$} & Control $(n=7)$ & Proband & & \\
\hline & $8.05 \pm 0.18$ & 7.49 & & \\
\hline
\end{tabular}

Arterial blood and venous blood were obtained from nine control cows and from the proband. The blood samples anticoagulated with heparin lithium were analyzed for blood gases, $\mathrm{pH}$, and electrolytes within $10 \mathrm{~min}$ after collection. The values are at $37^{\circ} \mathrm{C}$, and the actual body temperatures were $38.6 \pm 0.2^{\circ} \mathrm{C}$ and $38.7^{\circ} \mathrm{C}$ for control cattle and the proband, respectively. To measure $\mathrm{pH}_{\mathrm{i}}$, red cells from venous blood were washed and suspended $(\mathrm{Hct}=20 \%)$ in unbuffered saline followed by the addition of Triton $\mathrm{X}-100$ to $0.1 \%$ (vol/vol), and the $\mathrm{pH}$ of the lysate was measured. Urine $\mathrm{pH}$ was directly measured within $30 \mathrm{~min}$ after sampling. Data are expressed as means $\pm \mathrm{SD}$ (control, $n=9$ ) or the means of three examinations on the different days (proband) unless otherwise specified. $* n=4$ 
that of control cattle but was within the normal range $(\mathrm{pH}$ 7.4-8.4).

Although, as shown above, the total $\mathrm{CO}_{2}$ content in the proband blood was rather less than that in normal blood, $\mathrm{PCO}_{2}, \mathrm{PCO}_{2}$, and $\mathrm{O}_{2}$ saturation values were normal (Table III). Furthermore, the difference in total $\mathrm{CO}_{2}$ between venous and arterial blood in the proband $(1.7 \mathrm{mEq} /$ liter $)$ was within the normal range $(2.1 \pm 1.8[\mathrm{SD}] \mathrm{mEq} / \mathrm{liter} ; n=9)$, indicating that, in the lungs of the affected animal, $\mathrm{O}_{2} / \mathrm{CO}_{2}$ exchange was achieved as effectively as in normal cattle.

Ultrastructural studies on marked instability of the proband red cell membranes. To elucidate the pathogenesis of the moderate but chronic anemia with spherocyte formation in the sick animals, we examined morphological properties of the red cell membranes by electron microscopic analyses via several different methods. The membrane skeletal network in normal red cells appeared to be arranged in a cobblestone pattern in an essentially orderly fashion (Fig. $7 \mathrm{~A}$ ) and was composed of multiple smaller basic units connected to each other. Electron microscopic studies revealed that the basic membrane skeletal units were reasonably extended with thinner, evenly stretched fiber filaments with well-organized junctional units. In normal subjects, the size of the units was $54 \pm 14 \mathrm{~nm}$ (means $\pm \mathrm{SD}$ ) on the longer axis and $23 \pm 5 \mathrm{~nm}$ on the shorter axis. The membrane skeletal units were basically composed of thinner filaments in a folded conformation. These filaments were $48 \pm 9$ $\mathrm{nm}$ long and $7 \pm 1 \mathrm{~nm}$ wide. Knob-like structures, which were attached to the longer, thinner filaments, were also observed. These filaments of the intact membrane skeleton were demonstrated in multistereotactic dimensions by EM using the QFDE method.

The basic membrane skeletal units in the proband red cells varied in size and were mostly distorted (Fig. $7 \mathrm{~B}$ ). All of the fibrous filaments appeared to lose their interconnection with other filaments. Thus, the structure of the whole red cell membrane was clearly disorganized. The continuous three-dimensional network of fine filaments and small globules that had been observed in the normal control was totally disrupted with filaments of uneven length and width and a reduction in the number of intersections (Fig. $7 \mathrm{~B}$ ). The alignment of the network was disorderly. EM using the surface replica method demonstrated essentially the same results as those obtained by the QFDE method (not shown).

The proband red cells in the whole blood tended to lyse quickly if stored at $4^{\circ} \mathrm{C}$ even in the presence of plasma, compared with normal cells (not shown). At $4^{\circ} \mathrm{C}$, the proband red cells demonstrated a characteristic pseudopod-like formation as confirmed by EM with negative staining (Fig. 8).

Transmission EM studies revealed that the proband red cells from whole blood had many small rod-like or globule-like protrusions and projections on or along the surface of these cells (Fig. $9 A$ ), representing the vesiculation of small globules observed on these cells by scanning EM (Fig. 1). Within these relatively larger projections $(\sim 0.5 \mu \mathrm{m}$ in diameter), fine ultrastructures, which appeared to resemble the membrane structure, were detected. Extrusion of these microvesicles $(\sim 0.1$ $\mu \mathrm{m}$ in diameter), like exocytosis, was also observed (Fig. $9 A$ ). Vesicle-like structures were also present in the cytoplasm, which contained some amorphous or membrane-like ultrastructures, indicating that invagination or endocytosis had occurred. We demonstrated that these vesicles inside the cytoplasm contained bovine albumin, a plasma protein, by im-
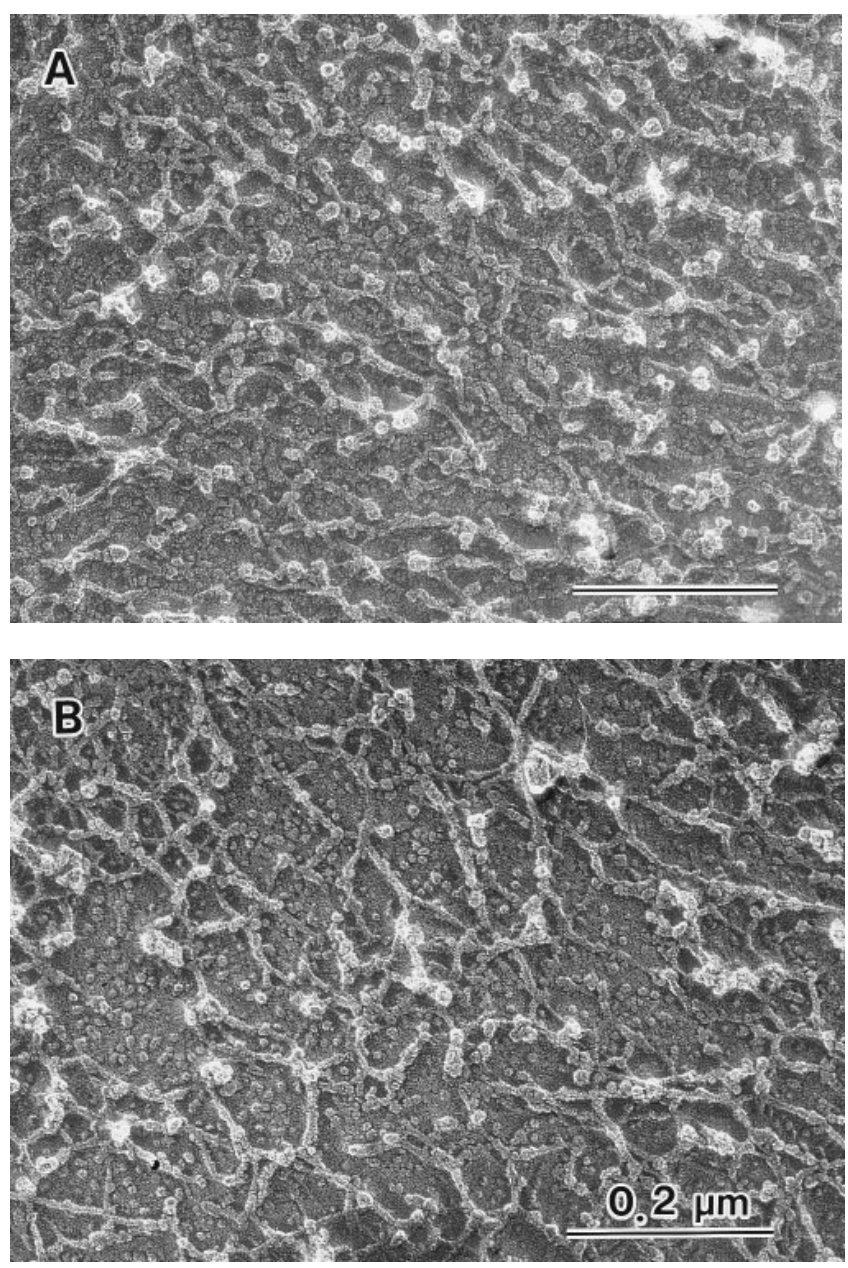

Figure 7. Disrupted membrane skeletal network in the proband red cells. Red cell ghosts were examined by transmission EM by using the QFDE method. The membrane skeletons in the proband with band 3 deficiency were totally disrupted and distorted with filaments of uneven length and width $(B)$ compared with the well-organized normal red cells $(A)$. Bars, $0.2 \mu \mathrm{m}$.

muno-EM as shown in Fig. 9 B. Uniform distribution of the immunogold particles within the vesicles indicated that the plasma proteins were occluded in them but not bound to the membrane. Albumin and other plasma proteins were also identified in the ghost membrane preparation by SDS-PAGE with immunoblotting using antibodies to bovine albumin and to bovine plasma proteins (not shown). These observations suggested that fragmentation of the membrane occurred in the proband red cells in several distinct ways, such as invagination, vesiculation, and extrusion of microvesicles.

The fragmented vesicles were obtained as sediment after low-speed centrifugation of a hypotonic lysate of the proband red cells (Fig. 10 $A$ ). The membrane protein profile in the vesicles was nearly identical to that of the original whole red cell ghosts (Fig. $10 \mathrm{~B}$ ). Therefore, $\alpha$ - and $\beta$-spectrins were clearly detected within the vesicle fraction on the immunoblot as shown in Fig. $10 C$.

\section{Discussion}

We described the first case in nature of complete deficiency of band 3, found in Japanese black cattle. To elucidate the molec- 


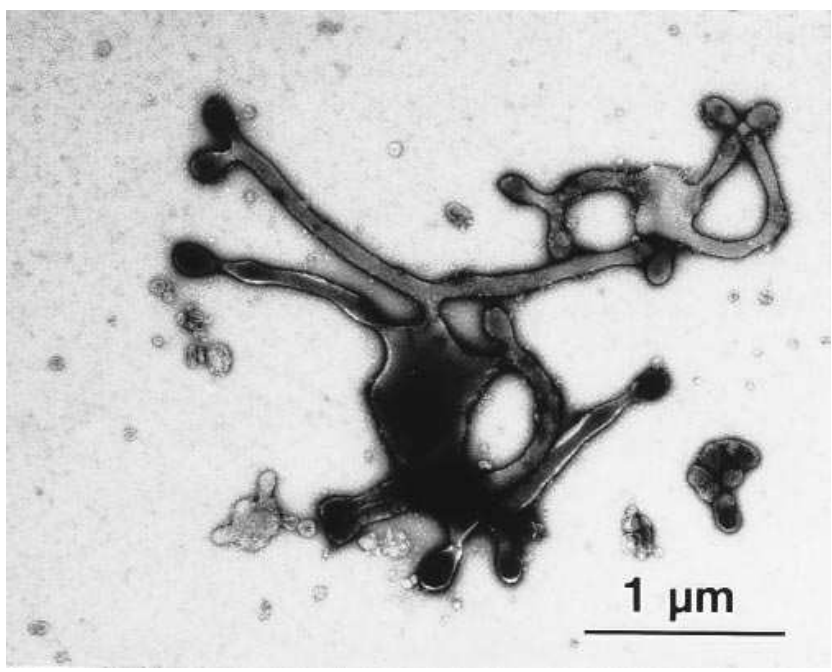

Figure 8. A characteristic pseudopod-like formation in the proband red cells. The intact red cells were placed at $4^{\circ} \mathrm{C}$ for $30 \mathrm{~min}$ and fixed for transmission EM with a negative staining method. Bar, $1 \mu \mathrm{m}$.

ular basis that underlies this aberrant deficiency of the band 3 protein, we analyzed the proband band 3 cDNA and genomic DNA and found a nonsense mutation $\mathrm{Arg}^{646} \rightarrow$ Stop (CGA $\rightarrow$ TGA). This mutation localizes in the extracellular face between membrane spans 7 and 8 of the red cell band 3 protein according to the secondary structure prediction (33). The presence of mRNA in proband bone marrow cells with a size identical to that in the control indicates that a mutant band 3 protein lacking the carboxyl-terminal half of the transmembrane domain would be produced. However, we did not detect the mutant protein, which was expected to be $70-80 \mathrm{kD}$, by immunoblotting even in bone marrow cells rich in erythroid precursor cells (Fig. 4). We, therefore, suppose that the total band 3 deficiency is caused by a rapid and complete loss of the mutant band 3 from the membrane after its synthesis or by a defective cotranslational insertion of the mutant protein into the endoplasmic reticulum membrane. The loss of the transmembrane protein with mutations has been suggested in several partial deficiencies of human band $3(17,18)$ and in the mutation of the cystic fibrosis transmembrane conductance regulator (47, 48). The possibility of a defective cotranslational insertion is less likely because the incorporation into microsomal membranes in the reticulocyte lysate system of truncated recombinants of human band 3 encoding the first 8 or 12 transmembrane spans has been demonstrated (49). Since we have not sequenced the proband band 3 cDNA entirely, we cannot rule out the possibility that there might be some other mutation leading to the total deficiency of this protein. However, the $\mathrm{Arg}^{646} \rightarrow$ Stop (CGA $\rightarrow$ TGA) mutation in the affected animals examined (P2 and $\mathrm{P} 4)$ and the presence in their dams of normal and mutant alleles indicated that this nonsense mutation was the principal molecular defect of the total deficiency of band 3 .

One of the most important findings for this aberrant deficiency of band 3 was the total lack of rapid anion transport in the proband red cells. This directly indicated the absence of an effective system for $\mathrm{O}_{2} / \mathrm{CO}_{2}$ transport between peripheral tissues and the lungs (5). However, waste $\mathrm{CO}_{2}$ produced in peripheral tissues of the proband appeared to be carried to the lungs and exchanged for $\mathrm{O}_{2}$ as effectively as in control cattle (Table III). This could be explained by a slight increase in $\mathrm{CO}_{2}$ dissolved in gaseous form. On the other hand, the proband cells showed intracellular alkalinization $(\sim 0.1 \mathrm{pH} \mathrm{U})$, most likely reflecting increased $\mathrm{HCO}_{3}{ }^{-}$with a simultaneous decrease of the $\mathrm{Cl}^{-}$concentration. Therefore, we also postulate that the $\mathrm{HCO}_{3}{ }^{-}$produced by carbonic anhydrase and accumulated within the red cells is transported to the lungs, where the increased $\mathrm{HCO}_{3}{ }^{-}$is converted to $\mathrm{CO}_{2}$ to exit the red cells followed by exchange for $\mathrm{O}_{2}$. This type of storage and carrying of $\mathrm{CO}_{2}\left(\mathrm{HCO}_{3}{ }^{-}\right)$does not require $\mathrm{HCO}_{3}{ }^{-}$to be transported out via band 3 . Thus, it is possible that the band 3 function in the
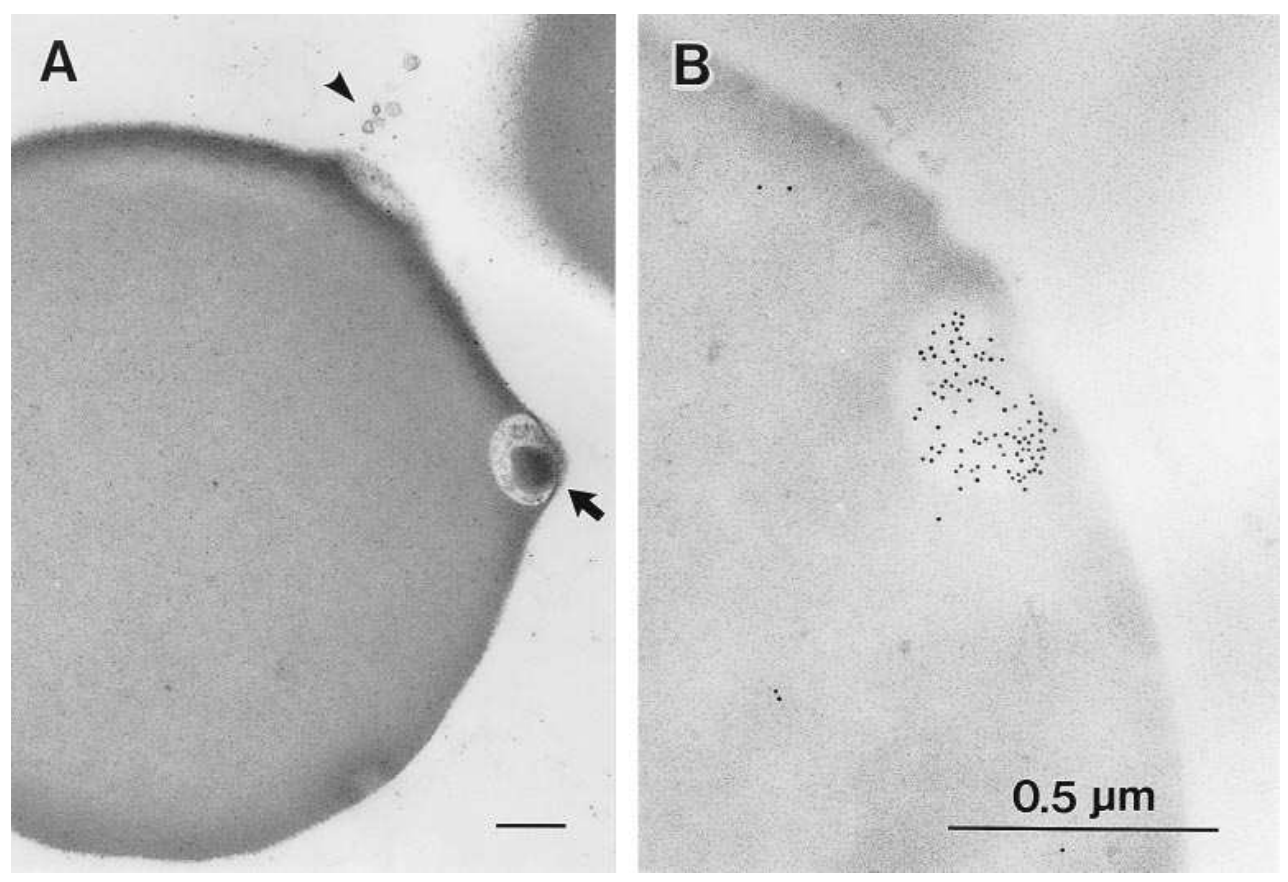

Figure 9. Marked exocytosis- and endocytosis-like protrusions and projections in the proband red cells. (A) Transmission EM shows many small rod-like or globule-like protrusions and projections along the cell surface and in the cytoplasm (arrow), suggesting the presence of invagination or endocytosis. Exocytic extrusion of microvesicles is also shown (arrowhead). (B) The vesicle-like structure inside the cytoplasm of the proband cells contained bovine albumin as judged by immuno-EM using anti-bovine albumin antibodies. Bars, $0.5 \mu \mathrm{m}$. 
A
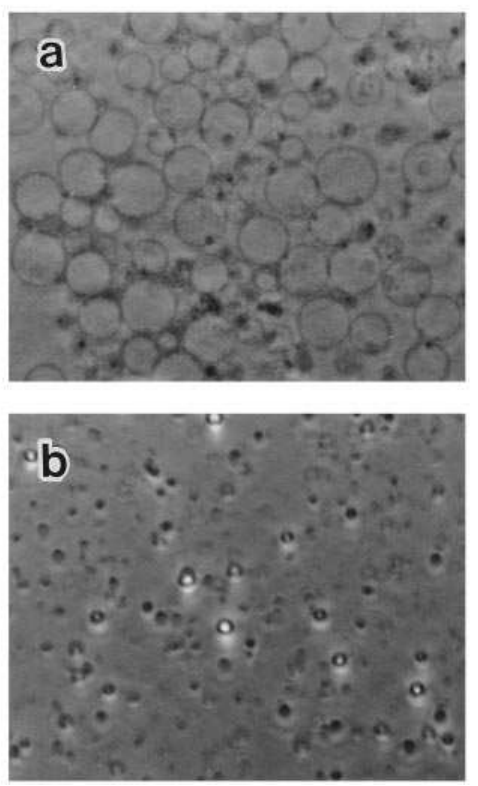

B

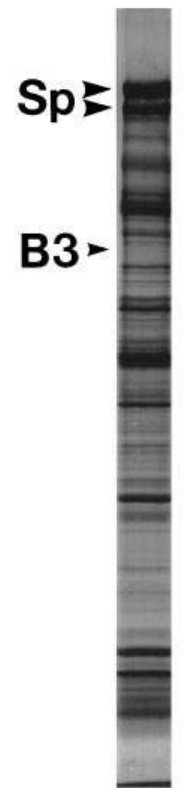

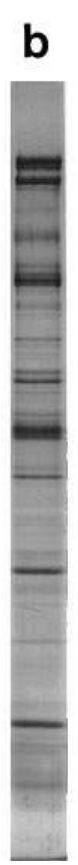

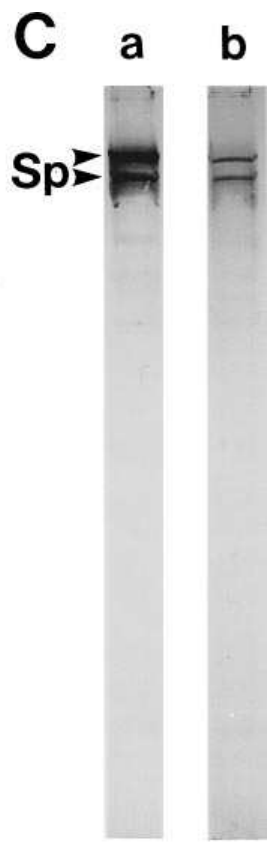

b
Figure 10. Membrane protein profiles and immunological detection of spectrins in the proband red cell ghosts and vesicles. Band $3-$ deficient red cells were lysed in $10 \mathrm{mM}$ Tris/ $\mathrm{Cl}, 1$ mM EDTA, pH 7.8, followed by centrifugation at $300 \mathrm{~g}$. Phase contrast micrographs $(A)$ indicate the supernatant containing larger ghosts $(a)$ and the sedimented vesicle fraction $(b)$. The larger ghosts $(a)$ and the vesicles $(b)$ were subjected to SDS-PAGE followed by staining with Coomassie brilliant blue $(B)$ and immunoblotting with anti-spectrin antibodies $(C)$.
$\mathrm{O}_{2} / \mathrm{CO}_{2}$ metabolism is not as critical as has been believed (1, 4, $5)$, although band 3-mediated transport would be more effective when $\mathrm{CO}_{2}$ waste and $\mathrm{O}_{2}$ demand are increased by vigorous motion or altitude, since it definitely facilitated the total $\mathrm{CO}_{2}$ carrying capacity by at least $20 \%$, as evidenced in this study by comparing the total $\mathrm{CO}_{2}$ in the proband and control cattle (Table III).

Previous investigators have suggested that total lack of band 3 function is lethal $(4,14,22)$, not only because of effects on red cell function, but also because of the contribution of band 3 in the collecting duct of the kidney, where it is involved in $\mathrm{HCO}_{3}{ }^{-}$reabsorption and acid secretion $(4,7,8)$. The present study demonstrated that complete lack of band 3 in the red cells and kidney indeed caused acidosis. However, the acidosis in the affected animals was mild $(\sim 0.15 \mathrm{pH} \mathrm{U})$ and the $\mathrm{pH}$ value of proband urine was lower than that in the normal cattle, suggesting that $\mathrm{H}^{+}$secretion by the kidney was effective. These results indicated the existence of a system that could compensate for the anion exchange function of band 3 to some extent. We have no definitive evidence concerning what fulfills this function. The system might affect not only the anion metabolism but also cations since the reduced blood $\mathrm{Na}^{+}$ concentration and the maintenance of an anion gap at the level of normal cattle were observed in the proband (Table III). Impaired acid-base homeostasis alters the metabolism of various tissues and cells mainly by changing $\mathrm{pH}_{\mathrm{i}}$ (50-53). Supposing that $\mathrm{pH}_{\mathrm{i}}$ regulation systems other than band 3 involving the $\mathrm{Na}^{+} / \mathrm{H}^{+}$antiporter and various other anion transporters are normal in other somatic cells, acidosis would lead to the reduction of $\mathrm{pH}_{\mathrm{i}}$ in those cells $(3,51,52)$. Targets for $\mathrm{pH}_{\mathrm{i}}$-mediated regulation involve glycolytic pathways (53), insulin action (53, $54)$, and cellular growth $(50,55)$. Thus, the acid-base disorder might have been, at least in part, the cause of the retarded growth of the proband.

It should be noted that four of the nine affected animals with total lack of band 3 survived to and thrived in adulthood (1-4 yr), whereas most of the others with severe clinical symp- toms died or were killed within $10 \mathrm{~d}$ after birth. The low viability during this period would intrinsically be due to severe hemolysis, which also occurred and subsequently disappeared in surviving cases. Thus, some physiological factors characteristic to neonatal calves would affect the magnitude of hemolysis and survival of the animals. Factors such as genetic background and animal husbandry, including supportive medical care at birth, also could contribute to differences in survival. It is therefore suggested that, once newborn calves survive the neonatal stage, the homozygous state of band 3 deficiency is compatible with life.

The most characteristic feature of the band 3-deficient cells was marked spherocytosis associated with fragmentation of the membrane as evidenced in a series of electron microscopic studies (Figs. 1, 8, and 9). Disruption of the membrane skeletal network, directly proved by the QFDE method (Fig. 7), corresponded well with the reduction of the membrane skeletal proteins (Fig. 2) and appeared to be the principal cause for membrane instability leading to the loss of the membrane. It is most likely that the reduction of membrane skeletal proteins was primarily due to the total lack of band 3 as their direct or indirect acceptor when these proteins were synthesized and assembled into the membrane. This is because the synthesis of band 3 only requires the membranous structure to be inserted (56), whereas the incorporation into the membrane of other skeletal proteins is regulated by the integral membrane proteins for their acceptors (57-59). That is, the absence of band 3 would cause a deficiency of ankyrin, which participates in stable assembly of the spectrin heterodimer into the membrane through band 3-ankyrin-spectrin linkage in concert with the function of glycophorin-protein 4.1-spectrin association. Hence, the spectrin-actin complex in the membrane would be decreased. Protein 4.2, which was nearly missing in the band 3-deficient cells, requires specific acceptors, such as band 3 , to be assembled into the red cell membrane even if its synthesis is normal, as shown by recent studies on protein 4.2 deficiency secondary to band 3 anomalies $(15,16)$. Therefore, 
the loss of the network organization resulting in the marked instability of the membrane was due to the total lack of the band 3 protein followed by striking reductions of spectrin, actin, ankyrin, and protein 4.2, and a consequent decrease in density of the network.

Another explanation for the network disorganization is an aberrant defect in the association of the membrane skeleton to the lipid bilayer through band 3-ankyrin-spectrin linkage itself, which is suggested to be essential to the mechanical stability of the membrane (9). This is consistent with several hypothetical pathways for the surface area loss in hereditary spherocytosis proposed by Palek and Jarolim $(20,21)$ according to the criteria that all putative pathways share defective vertical connections between the skeleton and the lipid bilayer. However, our current findings showed that vesicles released or fragmented from the original red cells contained various membrane proteins, including spectrin (Fig. 10), probably because of disorganization of horizontal interconnection of spectrin molecules as suggested by EM with the QFDE method (Fig. 7). This is incompatible with the observation that, in spherocyte formation primarily due to partial deficiency of spectrin, ankyrin, or band 3 , membrane loss occurs via a release of lipid vesicles $(\sim 0.2-0.5 \mu \mathrm{m}$ in diameter $)$ that contain band 3 but are devoid of spectrin $(20,21)$. Thus, although it is still unclear whether a population of the vesicles fragmented from the proband red cells is free of spectrin, we postulate that total deficiency of band 3 leads to disorganization of both vertical and horizontal interconnections of membrane proteins, resulting in striking instability of the membrane. We also observed some additional processes in the proband red cells, involving endocytic invagination and exocytic extrusion of microvesicles of $\sim 0.1 \mu \mathrm{m}$ in diameter. These phenomena appear to be similar to the formation and the release of exosomes found in various mammalian reticulocytes (60), although we as yet have no direct evidence. Based on these findings, we conclude that marked instability of the membrane due to total deficiency of band 3 may lead to spherocyte formation in several distinct ways, including invagination, vesiculation, and extrusion of microvesicles.

Although the chronic anemia in the proband was not accompanied by evident intravenous hemolysis, increased erythropoiesis in the bone marrow and the remarkably decreased protein $4.1 \mathrm{a} / 4.1 \mathrm{~b}$ ratio (61) in the proband red cell membranes (Fig. 2) indicated that newly produced red cells were continuously released into circulation, and that accelerated and continual destruction of red cells occurred in the proband. Therefore, we suppose that this process of destruction of band 3-deficient red cells, a major cause of chronic anemia, was not accompanied by severe hemolytic crisis but was mainly caused by continual membrane loss as described above.

In conclusion, the present study provides evidence that the major complaints of the affected animals-moderate anemia with spherocytosis, growth retardation, and acidosis-were all associated with complete deficiency of band 3. The results demonstrated that band 3 is definitely important in acid-base homeostasis, $\mathrm{O}_{2} / \mathrm{CO}_{2}$ transport, and membrane skeletal organization, as has long been suggested. However, it is also postulated that band 3 is not always essential, at least to the survival of cattle. Further understanding of the pathobiology of the band 3 deficiency in cattle will provide information enabling researchers to reexamine the roles of band 3 in a variety of mammals, including humans.

\section{Acknowledgments}

The authors thank Drs. Shio Makino and Ryuichi Moriyama (Nagoya University) and Dr. Naotaka Hamasaki (Kyushu University) for their antibodies and helpful discussion; Dr. Makoto Nakao (Showa University) for his enthusiastic discussion of this study; Drs. Motoshi Tajima, Osamu Yamato, Toshiyuki Murase, Naohiro Kaneko (all from Hokkaido University), Naoaki Matsuki, Mitsuhito Matsumoto (both from University of Tokyo), Dr. Daisaku Watanabe (Yamagata PFAMRA), and Dr. Katsuji Suzuki (Nippon Veterinary and Animal Science University) for their assistance.

This study was supported by Grants-in-Aid for Scientific Research (No. 05454122, 05670936, 05834001, 06556054, 06671120, 07305036, 07456140, 07457236, and 07670180) and for the International Scientific Research Program: Joint Research (No. 06044212) from the Ministry of Education, Science, and Culture of Japan; a research grant for Idiopathic Disorders of Hematopoietic Organs from the Japanese Ministry of Health and Welfare; grants from the Morinaga Memorial Foundation, the Itoh Memorial Foundation, the Suhara Memorial Foundation, and the Uehara Memorial Foundation; and grants from Kawasaki Medical School (No. 5-101, 6-106, and 7-104).

\section{References}

1. Jay, D., and L. Cantley. 1986. Structural aspects of the red cell anion exchanger protein. Annu. Rev. Biochem. 55:511-538.

2. Jennings, M.L. 1989. Structure and function of the red blood cell anion transport protein. Annu. Rev. Biophys. Biophys. Chem. 18:397-430.

3. Alper, S.L. 1991. The band 3-related anion exchanger (AE) gene family. Annu. Rev. Physiol. 53:549-564.

4. Tanner, M.J.A. 1993. Molecular and cellular biology of the erythrocyte anion exchanger (AE1). Semin. Hematol. 30:34-57.

5. Wieth, J.O., O.S. Andersen, J. Brahm, P.J. Bjerrum, and C.L. Borders, Jr. 1982. Chloride-bicarbonate exchanger in red blood cells: physiology of transport and chemical modification of binding sites. Phil. Trans. R. Soc. Lond. B299:383-399.

6. Hladkey, S.B., and T.J. Rink. 1977. $\mathrm{pH}$ equilibrium across the red cell membrane. In Membrane Transport in Red Cells. J.C. Ellory and V.L. Lew, editors. Academic Press, London. 115-135.

7. Wagner, S., R. Vogel, R. Lietzke, R. Koob, and D. Drenckhahn. 1987. Immunochemical characterization of a band 3-like anion exchanger in collecting duct of human kidney. Am. J. Physiol. 22:F213-F221.

8. Alper, S.L., J. Natale, S. Gluck, H.F. Lodish, and D. Brown. 1989. Subtypes of intercalated cells in rat kidney collecting duct defined by antibodies against erythroid band 3 and renal vascular $\mathrm{H}^{+}$-ATPase. Proc. Natl. Acad. Sci. USA. 86:5429-5433.

9. Low, P.S., B.M. Willardson, N. Mohandas, M. Rossi, and S. Shohet. 1991. Contribution of the band 3-ankyrin interaction to erythrocyte membrane mechanical stability. Blood. 77:1581-1586.

10. Mohandas, N., R. Winardi, D. Knowles, A. Leung, M. Parra, E. George, J. Conboy, and J. Chasis. 1992. Molecular basis for membrane rigidity of hereditary ovalocytosis. A novel mechanism involving the cytoplasmic domain of band 3. J. Clin. Invest. 89:686-692.

11. Liu, S.-C., S. Zhai, J. Palek, D.E. Golan, D. Amato, K. Hassan, G.T. Nurse, D. Babona, T. Coetzer, P. Jarolim, M. Zaik, and S. Borwein. 1990. Molecular defect of the band 3 protein in Southeast Asian ovalocytosis. N. Engl. J. Med. 323:1530-1538.

12. Tanner, M.J.A., L. Bruce, P.G. Martin, D.M. Rearden, and G.L. Jones. 1991. Melanesian hereditary ovalocytes have a deletion in red cell band 3 . Blood. 78:2785-2787.

13. Jarolim, P., J. Palek, D. Amato, K. Hassan, P. Sapak, G.T. Nurse, H.L. Rubin, S. Zhai, K.E. Sahr, and S.-C. Liu. 1991. Deletion in erythrocyte band 3 gene in malaria-resistant Southeast Asian ovalocytosis. Proc. Natl. Acad. Sci. USA. 88:11022-11026.

14. Schofield, A.E., D.M. Reardon, and M.J.A. Tanner. 1992. Defective anion transport activity of the abnormal band 3 in hereditary ovalocytic red blood cells. Nature (Lond.). 355:836-838.

15. Jarolim, P., J. Palek, H.L. Rubin, J.T. Prchal, C. Korsgren, and C.M. Cohen. 1992. Band 3 Tuscaloosa: $\operatorname{Pro}^{327} \rightarrow \mathrm{Arg}^{327}$ substitution in the cytoplasmic domain of erythrocyte band 3 protein associated with spherocytic hemolytic anemia and partial deficiency of protein 4.2. Blood. 80:523-529.

16. Rybicki, A.C., J.J.H. Qiu, S. Musto, N.L. Rosen, R.L. Nagel, and R.S. Schwartz. 1993. Human erythrocyte protein 4.2 deficiency associated with hemolytic anemia and a homozygous ${ }^{40}$ glutamic acid $\rightarrow$ lysine substitution in the cytoplasmic domain of band 3 (band $3^{\text {Montefiore }}$ ). Blood. 81:2155-2165. 
17. Jarolim, P., H.L. Rubin, S.-C. Liu, M.R. Cho, V. Brabec, L.H. Derick, S.J. Yi, S.T.O. Saad, S.L. Alper, C. Brugnara, et al. 1994. Duplication of 10 nucleotides in the erythroid band 3 (AE1) gene in a kindred with hereditary spherocytosis and band 3 protein deficiency (band $3^{\text {PRAGUE }}$ ). J. Clin. Invest. 93 : 121-130.

18. Jarolim, P., H.L. Rubin, V. Brabec, L. Chrobak, A.S. Zolotarev, S.L. Alper, C. Brugnara, H. Wichterle, and J. Palek. 1995. Mutations of conserved arginines in the membrane domain of erythroid band 3 lead to a decrease in membrane-associated band 3 and to the phenotype of hereditary spherocytosis. Blood. 85:634-640.

19. Palek, J., and K.E. Sahr. 1992. Mutations of the red blood cell membrane proteins: from clinical evaluation to detection of the underlying genetic defect. Blood. 80:308-330.

20. Palek, J., and P. Jarolim. 1993. Clinical expression and laboratory detection of red blood cell membrane protein mutations. Semin. Hematol. 30:249283.

21. Palek, J., and P. Jarolim. 1995. Hereditary spherocytosis, elliptocytosis, and related disorders. In Williams Hematology. 5th ed. E. Beutler, M.A. Lichtman, B.S. Coller, and T.J. Kipps, editors. McGraw-Hill Inc., New York. 536557.

22. Liu, S.-C., P. Jarolim, H.L. Rubin, J. Palek, D. Amato, K. Hassen, M. Zaik, and P. Sapak. 1994. The homozygous state for the band 3 protein mutation in Southeast Asian ovalocytosis may be lethal. Blood. 84:3590-3591.

23. Beutler, E. 1990. Osmotic fragility. In Hematology. 4th ed. W.J. Williams, E. Beutler, A.J. Erslev, and M.A. Lichtman, editors. McGraw-Hill Inc., New York. 1726-1728.

24. Inaba, M., and Y. Maede. 1988. A new major transmembrane glycoprotein, gp155, in goat erythrocytes. Isolation and characterization of its association to cytoskeleton through binding with band 3-ankyrin complex. J. Biol. Chem. 263:17763-17771.

25. Makino, S., R. Moriyama, T. Kitahara, and S. Koga. 1984. Proteolytic digestion of band 3 from bovine erythrocyte membranes in membrane-bound and solubilized states. J. Biochem. (Tokyo). 95:1019-1029.

26. Bradford, M.M. 1976. A rapid and sensitive method for quantification of microgram quantities of protein utilizing the principle of protein-dye binding. Anal. Biochem. 72:248-254.

27. Laemmli, U.K. 1970. Cleavage of structural proteins during the assembly of the head of bacteriophage T4. Nature (Lond.). 227:680-685.

28. Inaba, M., and Y. Maede. 1986. Na,K-ATPase in dog red cells. Immunological identification and maturation-associated degradation by the proteolytic system. J. Biol. Chem. 261:16099-16105.

29. Moriyama, R., S. Kawamatsu, Y. Kondo, M. Tomida, and S. Makino. 1989. Antigenic determinants of the cytoplasmic domain of band 3 from bovine erythrocyte membrane. Arch. Biochem. Biophys. 274:130-137.

30. Kawano, Y., K. Okubo, F. Tokunaga, T. Miyata, S. Iwanaga, and N. Hamasaki. 1988. Localization of the pyridoxal phosphate binding site at the COOH-terminal region of erythrocyte band 3 protein. J. Biol. Chem. 263:82328238 .

31. Inaba, M., Y. Amano, and Y. Maede. 1990. Two novel molecular isoforms of band 4.2 in Japanese Sika deer (Cervus nippon yesoensis, Heude) erythrocytes. Biochim. Biophys. Acta. 1021:101-104.

32. Tanner, M.J.A., P.G. Martin, and S. High. 1988. The complete amino acid sequence of the human erythrocyte membrane anion-transport protein deduced from the cDNA. Biochem. J. 256:703-712.

33. Lux, S.E., K.M. John, R.R. Koipito, and H.F. Lodish. 1989. Cloning and characterization of band 3, the human erythrocyte anion-exchange protein (AE1). Proc. Natl. Acad. Sci. USA. 86:9089-9093.

34. Moriyama, R., Y. Nagatomi, F. Hoshino, and S. Makino. 1994. Amino acid sequences around exofacial proteolytic cleavage sites of band 3 from bovine and porcine erythrocytes. Int. J. Biochem. 26:133-137.

35. Knauf, P.A., S. Ship, W. Breuer, L. McCulloch, and A. Rothstein. 1978. Asymmetry of the red cell anion exchange system. Different mechanisms of reversible inhibition by $\mathrm{N}$-(4-azido-2-nitorophenyl)-2-aminoethylsulfonate (NAPtaurine) at the inside and outside of the membrane. J. Gen. Physiol. 72:607-630.

36. Knauf, P.A., W. Breuer, L. McCulloch, and A. Rothstein. 1978. N-(4Azido-2-nitrophenyl)-2-aminoethylsulfonate (NAP-taurine) as a photoaffinity probe for identifying membrane components containing the modifier site of the human red blood cell anion exchanger system. J. Gen. Physiol. 72:631-649.

37. Law, F.-Y., R. Steinfeld, and P.A. Knauf. 1983. K562 cell anion exchange differs markedly from that of mature red blood cells. Am. J. Physiol. 244:C68-C74.

38. Inaba, M., and Y. Maede. 1984. Increase of $\mathrm{Na}^{+}$gradient-dependent L-glutamate and L-aspartate transport in high $\mathrm{K}^{+}$dog erythrocytes associated with high activity of $\left(\mathrm{Na}^{+}, \mathrm{K}^{+}\right)$-ATPase. J. Biol. Chem. 259:312-317.

39. Halperin, J.A., C. Brugnara, M.T. Tosteson, T.V. Ha, and D.C. Tosteson 1989. Voltage-activated cation transport in human erythrocytes. Am. J. Physiol. 257:C986-C996.

40. Yawata, Y. 1994. Red cell membrane protein band 4.2: phenotypic, genetic, and electron microscopic aspects. Biochim. Biophys. Acta 1204:131-148.

41. Yawata, A., A. Kanzaki, K. Uehira, and Y. Yawata. 1994. A surface replica method: a useful tool for studies of the cytoskeletal network in red cell membranes of normal subjects and a $\beta$-spectrin mutant (spectrin Le Puy: $\left.\beta^{220 / 214}\right)$. Virchows Archiv. 425:297-304.

42. Yawata, Y., A. Yawata, A. Kanzaki, T. Inoue, N. Okamoto, K. Uehira, M. Yasunaga, and Y. Nakamura. 1996. Electron microscopic evidence of impaired intramembrane particles and instability of the cytoskeletal network in band 4.2 deficiency in human red cells. Cell Motil. Cytoskeleton. 33:95-105.

43. Liu, S.-C., L.H. Derick, and J. Palek. 1987. Visualization of the hexagonal lattice in the erythrocyte membrane skeleton. J. Cell Biol. 104:527-536.

44. Doxey, D.L. 1977. Haematology of the ox. In Comparative Clinical Hematology. R.K. Archer, and L.B. Jeffcott, editors. Blackwell Scientific Publications, Oxford, UK. 215 pp

45. Low, P.S. 1986. Structure and function of the cytoplasmic domain of band 3: center of erythrocyte membrane-peripheral protein interactions. Biochim. Biophys. Acta. 864:145-167.

46. Cabantchik, Z.I., P.A. Knauf, and A. Rothstein. 1978. The anion transport system of the red blood cell. The role of membrane protein evaluated by the use of 'probes.' Biochim. Biophys. Acta. 515:239-302.

47. Cheng, S.H., R.J. Gregory, J. Marshall, S. Paul, D.W. Souza, G.A White, C.R. O'Riordan, and A.E. Smith. 1990. Defective intracellular transport and processing of CFTR is the molecular basis of most cystic fibrosis. Cell. 63 : 827-834.

48. Ward, C.L., and R.R. Kopito. 1994. Intracellular turnover of cystic fibrosis transmembrane conductance regulator: insufficient processing and rapid degradation of wild-type and mutant proteins. J. Biol. Chem. 269:25710-25718.

49. Groves, J.D., and M.J.A. Tanner. 1995. Co-expressed complementary fragments of the human red cell anion exchanger (band 3, AE1) generate stilbene disulfonate-sensitive anion transport. J. Biol. Chem. 270:9097-9105.

50. Busa, W.B., and R. Nuccitelli. 1984. Metabolic regulation via intracellular pH. Am. J. Physiol. 246:R409-R438.

51. Roos, A., and W.F. Boron. 1981. Intracellular pH. Physiol. Rev. 61:296434.

52. Ganz, M.B., G. Boyarsky, R.B. Sterzel, and W.F. Boron. 1989. Arginine vasopressin enhances pHi regulation in the presence of $\mathrm{HCO}_{3}^{-}$by stimulating three acid-base transport systems. Nature (Lond.). 337:648-651.

53. Fidelman, M.L., S.H. Seeholzer, K.B. Walsh, and R.D. Moore. 1982. Intracellular $\mathrm{pH}$ mediates action of insulin on glycolysis in frog skeletal muscle. Am. J. Physiol. 242:C87-C93.

54. Moore, R.D., M.L. Fidelman, and S.H. Seeholzer. 1979. Correlation between insulin action upon glycolysis and changes in intracellular $\mathrm{pH}$. Biochem. Biophys. Res. Commun. 91:905-910.

55. Poussegur, J., C. Sardet, A. Franchi, G. L'Allemain, and S. Paris. 1984 A specific mutation abolishing $\mathrm{Na}^{+} / \mathrm{H}^{+}$antiport activity in hamster fibroblasts precludes growth at neutral and acidic pH. Proc. Natl. Acad. Sci. USA. 81:48334837.

56. Braell, W.A., and H.F. Lodish. 1982. The erythrocyte anion transport protein is cotranslationally inserted into microsomes. Cell. 28:23-31.

57. Woods, C.M., B. Boyer, P.K. Vogt, and E. Lazarides. 1986. Control of erythroid differentiation: asynchronous expression of the anion transporter and the peripheral components of the membrane skeleton in AEV- and S13-transformed cells. J. Cell Biol. 103:1789-1798.

58. Koury, M.J., M.C. Bondurant, and S.S. Rana. 1987. Changes in erythroid membrane proteins during erythropoietin-mediated terminal differentiation. J. Cell. Physiol. 133:438-448.

59. Hanspal, M., J.S. Hanspal, R. Kalraiya, S.-C. Liu, K.E. Sahr, D. Howard, and J. Palek. 1992. Asynchronous synthesis of membrane skeletal proteins during terminal maturation of murine erythroblasts. Blood. 80:530-539.

60. Johnstone, R.M., A. Bianchini, and K. Teng. 1989. Reticulocyte maturation and exosome release: Transferrin receptor containing exosomes shows multiple plasma membrane functions. Blood. 74:1844-1851.

61. Inaba, M., K.C. Gupta, M. Kuwabara, T. Takahashi, E.J. Benz, Jr., and Y. Maede. 1992. Deamidation of human erythrocyte protein 4.1: possible role in aging. Blood. 79:3355-3361.

62. Brahm, J. 1977. Temperature-dependent changes of chloride transport kinetics in human red cells. J. Gen. Physiol. 70:283-306. 